The Federal Reserve BanK of KANSAS City ECONOMIC RESEARCH DEPARTMENT

\title{
Executive Compensation and Business Policy Choices at U.S. Commercial Banks
}

Robert DeYoung, Emma Y. Peng, Meng Yan

January 2010

RWP 10-02 


\title{
Executive Compensation and Business Policy Choices at U.S. Commercial Banks*
}

\author{
Robert DeYoung \\ University of Kansas, KU School of Business \\ Visiting Scholar, Federal Reserve Bank of Kansas City \\ Emma Y. Peng \\ Fordham University, Graduate School of Business Administration \\ Meng Yan \\ Fordham University, Graduate School of Business Administration
}

\author{
January 2010 \\ RWP 10-02 \\ Research Division \\ Federal Reserve Bank of Kansas City
}

\begin{abstract}
This study examines whether and how the terms of CEO compensation contracts at large commercial banks between 1994 and 2006 influenced, or were influenced by, the risky business policy decisions made by these firms. We find strong evidence that bank CEOs responded to contractual risk-taking incentives by taking more risk; bank boards altered CEO compensation to encourage executives to exploit new growth opportunities; and bank boards set CEO incentives in a manner designed to moderate excessive risk-taking. These relationships are strongest during the second half of our sample, after deregulation and technological change had expanded banks' capacities for risk-taking.
\end{abstract}

\footnotetext{
* DeYoung: University of Kansas, School of Business, 1300 Sunnyside Ave., Lawrence, KS 66045. Peng: Fordham University, Graduate School of Business, 1790 Broadway, 13th Floor, New York, NY 10019. Yan: Fordham University, Graduate School of Business, 1790 Broadway, 13th Floor, New York, NY 10019. We thank seminar participants at the Federal Deposit Insurance Corporation, the Federal Reserve Bank of Kansas City, the University of Kansas, and the University of Mississippi for their helpful comments and suggestions on this research. The views expressed in this paper are those of the authors and do not necessarily reflect the views of the Federal Reserve Bank of Kansas City or the Federal Reserve System.
} 
The historic collapse of U.S. home values, and the subsequent losses incurred by investors in mortgage-backed securities, wreaked havoc on the capital positions of both large and small financial institutions around the world. The market value of the global banking industry declined by slightly more than half during 2008, while the market capitalization of the ten largest U.S. commercial banks fell by about $65 \% .{ }^{1}$ To prevent the most heavily impacted banks from collapsing, the U.S. Treasury injected over $\$ 300$ billion in preferred and common equity capital into commercial banking companies through its Troubled Asset Relief Program (TARP). The Treasury and the Federal Reserve provided an even larger amount of aid —in the form of equity injections, loans, and loss guarantees - to rescue the hugely insolvent financial firms American International Group (AIG), Fannie Mae, Freddie Mac, and Bear Stearns.

Politicians and policymakers quickly sought to limit the compensation of executives at the banking companies that received taxpayer support. In March 2009, a second round of TARP capital injections was made contingent on executive pay limits. Also in March, President Obama instructed Treasury Department to "pursue every legal avenue" to block bonuses due to executives and other financial professionals at AIG: ${ }^{2}$

"This is a corporation that finds itself in financial distress due to recklessness and greed... Under these circumstances, it's hard to understand how derivative traders at AIG warranted any bonuses, much less \$165 million in extra pay. How do they justify this outrage to the taxpayers who are keeping the company afloat?”

A few days later the House of Representatives joined the fray, passing a bill that placed a confiscatory $90 \%$ tax on compensation above $\$ 250,000$ at any financial institution that received

1 Estimates from the Boston Consulting Group (2009) and Reuters (2009), respectively.

2 "Obama Asks Geithner to Find Way to Rescind AIG Payouts," Wall Street Journal March 16, 2009, http://online.wsj.com/article/SB123721970101743003.html?mod=djemalertNEWS. 
more than \$5 billion from TARP. Although this measure did not become law, both Congressional members and the Administration continue to advocate for new rules to govern executive pay, e.g., by increasing shareholder power and board responsibility over the terms of compensation contracts, by strengthening bank supervisors' ability to monitor and restrict executive pay, or by imposing outright restrictions on pay practices thought to encourage shortrun risk taking at the expense of long-run firm value. ${ }^{3}$ In October 2009, the Treasury's "special master for compensation” Kenneth Feinberg used authority granted by Congress to rewrite the compensation contracts of the 25 highest paid employees at each of the seven largest TARP recipients, slashing executive salaries and shifting compensation to longer term stock grants. Simultaneously, the Federal Reserve proposed reviewing the pay practices at 28 large, complex banking organizations "to determine their consistency with the principles for risk-appropriate incentive compensation."4

Government interference in private firm executive compensation has been rare in the U.S. $^{5}$ But the massive taxpayer assistance to large financial firms in 2008 and 2009 has generated substantial popular support for government intervention to control and/or punish “recklessness and greed.” Good public policy, however, should be based on less subjective phenomena. If one argues for a government role in setting the terms of bank executive pay, then

${ }^{3}$ See "Cuomo, Frank Seek to Link Executive Pay, Performance," Wall Street Journal On-line, March 13, 2009; "U.S. Eyes Bank Pay Overhaul," Wall Street Journal, May 13, 2009, page 1; and "Investors Take Note: New Bill to Target Boards, Say on Pay,” Wall Street Journal On-line, May 24, 2009, http://online.wsj.com/article/SB124061794487355095.html.

${ }^{4}$ Press Release, Federal Reserve Board of Governors, October 22, 2009.

${ }^{5}$ One example is the Omnibus Budget Reconciliation Act of 1993 which capped the corporate tax deduction for a firm's five highest paid managers to $\$ 1$ million; beyond this amount, only "qualified performance-based pay" merits a deduction. The law was intended to better align executive compensation with corporate performance. Gritsch and Snyder (2005) find that stock option compensation has increased as a result of this change. 
one must also be willing to argue that the incentives embedded in existing compensation arrangements either directly or indirectly lead to such risk-management mistakes, and moreover that bank boards take insufficient action to correct these incentive problems once they arise. Accordingly, in this study we devise and implement empirical tests of two relevant questions. First, were the incentives in executive compensation contracts at U.S. commercial banks during the 1990s and 2000s systematically associated with excessive risk-taking and financial mismanagement? Second, did bank boards adjust executive pay incentives to counter mismanagement and excessive risk-taking? A role for government intervention requires an affirmative answer to the first question, a negative answer to the second question, and a belief that intervention can have a net positive impact on social welfare (i.e., not make things worse).

The financial performance of any company is driven by three key elements: the business model in place, how well executives execute that business model, and external conditions beyond the control of executives. These three elements converged in late-2007 for many of the largest U.S. financial companies, with dire results. For much of the preceding two decades, large commercial banks had been transitioning their retail businesses away from the traditional “originate-and-hold" lending model that relies on interest income generated from repeat borrower-lender relationships, and toward an “originate-and-securitize” lending model that relies heavily on the fee income generated by non-repeat, arms-length financial transactions. This new business model channeled trillions of investor dollars to mortgage borrowers, in exchange for which the investors (primarily commercial and investment banks, insurance companies, and 
pension funds) held mortgage-backed securities (MBS) and/or derivatives of MBS. ${ }^{6}$ This approach generated record earnings for banks from the mid-1990s through the mid-2000s; however, these were years of relatively benign economic conditions, and growing this business model absent the disciplining effects of economic stress encouraged excesses. ${ }^{7}$ The collapse of the housing bubble exposed these excesses, most notable the investment grade-rated securitizations of subprime mortgages that performed so abysmally once home prices stopped rising. In retrospect, it is now clear that managers at commercial and investment banks also committed a number of fundamental risk-management mistakes. Portfolios were over-weighted in MBS, as institutional investors underestimated the covariances of housing prices across regions. ${ }^{8}$ Financial leverage was often excessive, whether funding MBS investments on the balance sheet or in off-balance sheet investment vehicles. And these levered portfolios of longterm assets were often financed with short-term debt, suggesting that managers forgot or simply ignored the key lessons of the 1980s savings and loan crisis.

Throughout this transformation of the large bank business model, the total compensation paid to CEOs at the largest U.S. commercial banks differed little from the total compensation paid to CEOs at large U.S. industrial corporations (see Figure 1). However, the incentives

\footnotetext{
${ }^{6}$ These derivatives include interest-only and principal-only instruments backed by pools of mortgages, and more complex collateralized debt obligations (CDOs) backed by pools of MBSs. Loan securitization has also increased in credit card, auto loan, student loan, and small business credit markets; however, financial losses on the asset-backed securities created in these transactions have not occurred as quickly, nor have they been as large, as for MBS.

${ }^{7}$ Between 1991 and 2007 there was only a single, relatively shallow recession. And ironically, the consumer spending generally credited for the mildness of the 2001 recession was made possible by mortgage securitization, which permitted homeowners to more readily access the equity that would previously been locked up in their homes.

${ }^{8}$ This view was not limited to investors in home real estate securities. Alan Greenspan famously stated during congressional testimony that upward pressure on home prices was largely a regional phenomenon and that nationwide declines in home prices were unlikely. (Testimony to Congress on July 20, 2005.)
} 
embedded in these two sets of compensation packages diverged markedly. We measure these incentives using two proxies. Pay-risk sensitivity, or vega, is the change in CEO wealth (in dollars) with respect to changes in stock return volatility (in annualized standard deviations). Pay-performance sensitivity, or delta, is the semi-elasticity of CEO wealth (in dollars) to changes in the firm's stock price (in percent). As measured by vega (see Figure 2), the risk-taking incentives of bank CEOs diverged permanently and substantially from those of non-bank CEOs around 2000-about the time the Gramm-Leach-Bliley Financial Modernization Act of 1999 allowed banks to engage more fully in home mortgage securitization and other nontraditional banking activities. ${ }^{9}$

We test whether and to what degree CEO vegas and CEO deltas influenced, or were influenced by, business policy decisions at the largest U.S. commercial banking companies between 1994 and 2006. Our multiple-equation model allows for simultaneity among vega, delta, and business policies. We find plentiful evidence to suggest that bank business policies are influenced by the incentives present in CEO compensation contracts. On average, high-vega banks generate a larger percentage of their incomes from nontraditional banking activities, invest a larger percentage of their assets in private (i.e., subprime or otherwise non-conforming) mortgage securitizations and a smaller percentage of their assets in on-balance sheet portfolios of real estate loans, and take on more credit risk. Importantly, this bundle of relatively risky

\footnotetext{
${ }^{9}$ While there were other changes in the executive compensation environment during our sample period (e.g., Chhaochharia and Grinstein (2009) find that rule changes at U.S. stock exchanges in 2001 and 2002 aimed at enhancing board oversight were associated with reductions in CEO compensation), we focus on the housing bubble and the Financial Modernization Act because these were first-order changes in the environment for U.S. commercial banking companies.
} 
business policies also exposes high-vega banks to greater systematic risk, and thus exacerbates the financial stress often experienced by banks during macroeconomic downturns. These business policy choices became more responsive to CEO vega in the second half of our sample, after Gramm-Leach-Bliley expanded the investment opportunity set for commercial banks. The evidence also suggests that bank boards are influenced by existing bank business policies when they set the risk-taking incentives in CEO compensation. These findings are strongest in the years following industry deregulation, when the data suggest that compensation committees began constraining risk-taking at high-risk banks while encouraging risk-taking at low-risk banks, and began providing increased incentives for CEOs to exploit new growth opportunities-e.g., by encouraging management to shift from traditional on-balance sheet portfolio lending to investments in private-issue mortgage-backed securities and nontraditional fee-generating activities.

The remainder of the paper is organized as follows. Section I discusses the transactions banking model central to the expansion of mortgage credit in the U.S. and how the adoption of this model has affected bank financial performance. Section II reviews the relevant literature on executive compensation and risk-taking. Section III presents our empirical model, defines the variables we use to specify the model, and identifies the specific hypotheses we are testing. Section IV describes the data. Section V reports our empirical results. Section VI summarizes the findings and discusses their implications.

\section{Transactions banking}


U.S. commercial banking companies have grown immensely larger over the past two decades, due mainly to the confluence of three factors. First, innovations in financial markets and information technologies created new options for depositors and savers (e.g., money market mutual funds, 401K plans, discount brokerage) and borrowers (e.g., commercial paper, highyield debt, OTC stock markets) and set in motion a process of disintermediation that threatened to make the heavily regulated U.S. banking sector obsolete. Second, federal deregulation allowed banks to expand their geographic footprints across state lines (the Riegle-Neal Interstate Banking and Branching Efficiency Act of 1994) and expand into non-banking products such as investment banking, brokerage, and insurance sales and underwriting (the Gramm-Leach-Bliley Financial Services Modernization Act of 1999). Third, a scale-intensive business model, often referred to as "transactions banking," emerged. This new banking business model is based on new channels of information (credit bureaus), new financial processes (asset securitization) and generates high volumes of noninterest (fee-based) income for banking companies that grow large enough to efficiently implement it.

Transactions banking embraces financial disintermediation. Banks use their traditional expertise in loan underwriting to originate loans, but instead of issuing deposits to fund these loans on-balance sheet they (or their investment bank partners) issue securities to fund large pools of loans in off-balance sheet loan securitizations. Loan securitizations are investment trusts that purchase existing home mortgage loans (or auto loans, credit card receivables, etc.) using funds raised by selling mortgage-backed securities (MBSs) to third-party investors; these investors are usually other financial institutions who want exposure to the risks and returns of 
diversified pools of mortgage loans without having to generate these loans themselves. Securitization allows banks to sell their otherwise illiquid loans and use the proceeds to fund additional loans_-in a sense, recycling bank capital. Banks earn fee income from originating, securitizing, and servicing the loans, while MBS investors receive all the interest payments and principal repayments. Depending on the terms of the securitization, the originating or securitizing banks may hold a portion of the MBSs themselves or provide recourse agreements to MBS investors.

Well over half of all U.S. residential mortgage debt is securitized by, guaranteed by, or held in the portfolios of government-sponsored enterprises (GSEs) such as Fannie Mae, Freddie Mac, and Ginnie Mae. Most of the MBSs issued by these GSEs are relatively safe and easy-tounderstand "pass-through" securities: the pooled mortgages are either backed by government guarantees, private insurance, or large down payments, and the interest and principal cash flows are shared equally by the investors. ${ }^{10}$ But investors in private (non-GSE) mortgage-backed securities can bear substantial risk. These MBS are backed by pools of loans with different and potentially riskier characteristics: large (jumbo) principals, low down payments, no mortgage insurance, low borrower creditworthiness (subprime loans) or incomplete documentation of borrower income (low-doc or “Alt-A” loans).

\footnotetext{
${ }^{10}$ Fannie Mae and Freddie Mac initially securitized or held only conforming mortgages (non-jumbo first mortgages with either $20 \%$ down payments or private mortgage insurance), as because of this were permitted to operate with very little capital; moreover, their lines of credit at the U.S. Treasury created the perception that they were "too-bigto-fail," which gave them a funding advantage over their private-sector competitors. But in response to political and regulatory pressure to make mortgage credit available to low- and moderate-income home buyers, both Fannie and Freddie began purchasing and holding MBSs backed by non-conforming loans. As these investments soured in the mid-2000s and the GSEs reached the verge of insolvency, the Treasury Department made good on its "implicit government guarantee” by injecting equity funding and nationalizing ownership of the two GSEs.
} 
Transactions banks gain access to enormous economies of scale (Hughes, Lang, Mester, and Moon (1996), Rossi (1998)) associated with the collection and analysis of the "hard," quantifiable borrower information central to the automated lending processes used to evaluate, originate, and pool large volumes of retail loans (Stein (2002)). But because transactions banks all have access to the same information (e.g., credit scores) and all produce non-differentiated financial commodities such as mortgage loans and credit card loans, price competition is intense and profit margins are tight. Hence, transactions banks have strong incentives to grow larger in order to exploit further unit cost reductions. Once external growth options (i.e., acquiring other transactions banks) are exhausted, internal growth requires increasing the number of loan originations, which creates an incentive to relax lending standards and make loans to less creditworthy borrowers. This incentive is exacerbated by the fact that, in this business model, loan underwriting is separated from both loan monitoring and the bearing of credit risk. Aside from the reduction in idiosyncratic credit risk associated with loan pooling, and any recourse arrangements with the originating or securitizing banks, MBS investors bear the bulk of the credit risk in this model, and given the information problems associated with pools comprised of hundreds or thousands of individual loans, these investors typically cede the task of evaluating risk to third-party securities rating firms.

Large banking companies have become more reliant on noninterest income over time—in large part because of the shift from originate-and-hold banking to originate-and-securitize banking, but also from expansion into new fee-based lines of business made accessible by industry deregulation such as securities underwriting and brokerage. This shift has tended to 
increase the volatility of bank earnings and banks' exposure to systematic risk. DeYoung and Roland (2001) show that (non-deposit-related) fee income is associated with higher revenue volatility, higher operating leverage, and higher earnings volatility at U.S. commercial banks. DeYoung and Rice (2004) find that marginal increases in non-interest income are associated with a worsening of banks' risk-return trade-off. Stiroh (2004a, 2004b) finds no evidence of diversification gains at banks that combine interest and non-interest income. Choi, DeYoung, and Hasan (2006) find that noninterest income at commercial banking companies in 42 different countries is strongly and positively related to systematic risk. Clark, Dick, Hirtle, Stiroh, and Williams (2007) emphasize how the increasingly retail-focused strategies of large U.S. banking companies expose these banks to economic and business cycle volatility. Elysiani and Wang (2008) demonstrate that noninterest income makes it more difficult for analysts to forecast the quarterly earnings of banking companies.

While the headlines in the financial press have justifiably dwelled on the over $\$ 2$ trillion of capital losses suffered by banks and other investors in sub-prime mortgage-backed securities, transactions banking companies have also experienced material, and in some cases crippling, reductions in fee income as investor demand for new MBS dried up and household demand for both new and existing houses declined. Total noninterest income in the U.S. banking industry fell from 43\% to 38\% of operating income between 2006 and the first three quarters of 2008, the largest two-year decline since the mid-1970s. Many of the largest financial institutions with non-diversified, "mono-line" mortgage banking strategies failed (e.g., American Home Mortgage, New Century Financial, Countrywide Financial, Washington Mutual, Golden West- 
Wachovia) due to the combined impact of plummeting fee income and large losses in their portfolios of subprime mortgages and mortgage-backed securities.

\section{Executive Compensation}

The manner in which corporate managers are compensated can shape their incentives, and delta and vega are two important measures of those incentives (Core and Guay (2002)). Vega, or pay-risk sensitivity, captures the change in the dollar value of CEO wealth for a 0.01 change in stock return volatility. Typically, including a large amount of stock option grants in CEO compensation packages will result in high vega. Delta, or pay-performance sensitivity, measures the change in the dollar value of $\mathrm{CEO}$ wealth for a $1 \%$ change in stock price. Typically, including a large amount of stock grants (and to a lesser extent, stock option grants) in CEO compensation packages will result in high delta.

The impact of delta on manager incentives is not straightforward. As a first principle, high-delta compensation reduces conflicts of interest between managers and shareholders by linking manager wealth to the value of the firm's stock (Jensen and Meckling (1976), Morck, Shleifer, and Vishny (1988), McConnell and Servaes (1990), Berger, Ofek, and Yermack (1997, Datta, Iskandar-Datta and Raman (2001)). But high-delta compensation may over time concentrate managerial wealth in the shares of the firm and create new principal-agent problems. The primary concern is that poorly diversified managers with high deltas may become riskaverse and pass up positive-NPV projects that carry high absolute levels of risk (Smith and Stulz

(1985)). However, shareholding managers can benefit along with the other equity investors if risk is shifted to debt-holders, and the extent to which such shifting is possible gives high-delta 
managers an incentive to take more risk (John and John (1993)); this may be an especially legitimate concern in our study, given that asset substitution problems can be more serious in banks where a large portion of debt is in the form of deposit contracts guaranteed by the Federal Deposit Insurance Corporation (FDIC).

The impact of vega on manager incentives is more clear. Because it rewards stock return volatility, high-vega compensation should make risk more valuable to managers and mitigates potential managerial risk aversion (Jensen and Meckling (1976), Smith and Stulz (1985)). Several studies provide evidence that high-vega compensation encourages riskier policy choices while high-delta compensation encourages less risky policy choices (Knopf, Nam, and Thornton (2002), Rogers (2002), Nam, Ottoo, and Thornton (2003), Coles, Daniel, and Naveen (2006)).

Vega and delta are not necessarily exogenous. Boards are likely to set the parameters of CEO compensation in conjunction with the business policies put in place by managers, either to complement those policies or to influence the amount of risk managers take in the implementation of those policies. For example, firms that face growing market demand might choose high-vega compensation to encourage the risk-taking necessary to grow the firm rapidly and take advantage of the new investment opportunities. Guay (1999) suggests that firms with more growth options are more likely to have high-vega contracts. Coles, Daniel, and Naveen (2006) further show that vega increases in R\&D expenditures, firm focus, and leverage, while vega decreases in investments in plant assets. Ge'czy, Minton and Schrand (2007) find that firms for which speculation (in interest rates, exchange rates, etc.) is a core business activity tend to use incentive-aligning compensation and bonding arrangements for their managers. 
The empirical evidence cited so far comes from studies of non-financial firms; as noted by Macey and O’Hara (2003, p.91), “very little attention has been paid to the corporate governance of banks.” This is likely due to the fact that, until recently, federal and state banking laws had tightly controlled banks’ risk-taking opportunities and strictly limited competition among banks. Absent risk-taking opportunities, executive compensation in the banking industry traditionally has not been structured to encourage risk-taking (Smith and Watts (1992), Houston and James (1995)). This appears to have changed with industry deregulation, which expanded banks' investment opportunities by allowing them to expand into new geographic markets (the Reigle-Neal Act of 1994) and provide non-commercial banking financial services such as investment banking, securities brokerage, and insurance sales and underwriting (the GrammLeach-Bliley Act of 1999). As discussed above, the data in Figure 2 strongly suggest that bank boards reshaped the risk-taking incentives of bank CEOs beginning around 1999 or 2000, consistent with encouraging executives to exploit new non-commercial banking growth options.

The nature of the bank production function-coupled with the responses of government regulation to the externalities endemic to that production technology—has had a profound effect on the governance environment at banks (Macey and O’Hara (2003)). Banks create liquidity for the economy by financing illiquid assets with liquid (in fact, payable upon demand) deposit liabilities. This production process can become unstable, with potentially dire consequences for the macro-economy, should depositors demand their funds en masse, i.e., a "bank run.” While the provision of government deposit insurance has for all intents and purposes eliminated the threat of bank runs in the U.S., it has also (a) reduced depositor incentives to monitor bank 
management, (b) greatly increased banks' capacities to take on financial leverage, and (c) increased the incentives for managers of financially troubled to invest in high-risk, negative net present value projects. Hostile takeovers are virtually absent from the banking industry (due to regulatory restrictions and approvals for large bank ownership stakes), eliminating another source of external monitoring and discipline of bank management. Thus, unlike most corporations, at banks the government supervisors perform an important monitoring function for outside shareholders. Against this backdrop, Adams and Mehran (2003) find that the corporate governance structures at bank holding companies between 1986 and 1999 were substantially different than those at other corporations: banking companies had larger boards with more outside directors, had less institutional ownership, and paid their CEOs relatively larger cash compensation (salary and bonus) but relatively smaller stock grants and stock options grants.

Only a small number of studies have examined the pay-performance and pay-risk sensitivities of bank CEO compensation and/or the impact of those sensitivities on bank risktaking and bank financial performance. A clear pattern has yet to develop in this literature. Hubbard and Palia (1995) find stronger pay-performance relationships in deregulated interstate banking markets where investment opportunities are arguably greater. Chen, Steiner, and Whyte (2006) find that option-based compensation was positively related to market-based risk measures at U.S. banks during the 1990s. Minnick, Unal and Yang (2009) study acquisitions made by U.S. banking companies between 1991 and 2005, and find that mergers are more likely to be value-enhancing, and post-acquisition operating performance more likely to be strong, when CEOs have high pay-performance compensation. Fahlenbrach and Stulz (2009) find no 
systematic relationship between CEO stock option compensation and U.S. banking company performance during the financial crisis in 2008, but do find a negative cross-sectional relationship between performance and CEO stock grant compensation.

\section{Model}

Our main focus is on the interplay of CEO vega and bank policy choices-however, we also include CEO delta in our tests, because managers will obviously react to $\underline{\text { all }}$ of the incentives embedded in their contracts. As discussed above, the relationships between and among these three variables are complex, and we test them in a fully endogenous and simultaneous system of equations:

$$
\begin{aligned}
& \text { Policy }_{t}=f\left(\operatorname{lnVega}_{t}, \operatorname{InDelta}_{t}, \text { InAssets }_{t-1}, \operatorname{lnMB}_{t-1}, \text { Equity ratio }_{t-1}, \text { EconCond }_{t}, \text { Year }_{t}\right) \\
& \operatorname{lnVega}_{t}=f\left(\text { Policy }_{t}, \text { InDelta }_{t}, \text { InAssets }_{t-1}, \operatorname{lnMB}_{t-1}, \text { Equity ratio }_{t-1}, \text { InSalary }_{t}, \text { Year }_{t}\right) \\
& \operatorname{lnDelta}_{t}=f\left(\text { Policy }_{t}, \text { InVega }_{t}, \quad \text { InAssets } t-1, \operatorname{lnMB}_{t-1}, \text { Equity ratio }_{t-1}, \text { Tenure }_{t}, \text { Year }_{t}\right)
\end{aligned}
$$

where $t$ indexes time and the index for individual banks is suppressed for convenience. Policy is any one of ten separate bank performance or product mix measures conventionally associated with high risk. We provide a detailed description for each of the Policy variables below. Vega and Delta are CEO wealth sensitivity measures estimated annually for each bank using the "oneyear approximation method" described below. Because the estimated variables have distributions heavily skewed to the right, we specify them in natural logs as $\ln V e g a_{t}$ and $\operatorname{lnDelta}{ }_{t}$. 
We employ a parsimonious specification. ${ }^{11}$ Each of the equations include three common control variables, observed at the beginning of time $t$ : the log of total assets (InAssets) accounts for differences in firm size, the log of the market-to-book equity ratio $(\ln M B)$ accounts for differences in bank-specific investment opportunities, and the ratio of book equity to assets (Equity ratio) accounts for differences in financial leverage across firms. Each of the equations also contains a unique control variable. The Policy regression (1) includes a market-weighted economic conditions variable $\left(\right.$ EconCond $\left._{t}\right)$ which varies over time with economic conditions and varies across banks based on the percentage of their deposits raised in each of the states in which they operate branches. ${ }^{12}$ We expect banks facing stronger (weaker) economic conditions will have more (less) leeway for choosing risky business policies. The Vega regression (2) includes the natural log of CEO salary (InSalary). Cash compensation allows the CEO to diversify outside the firm, thus reducing risk aversion and permitting lower risk-taking incentives (Guay (1999)) or may be an indication of CEO entrenchment, thus inducing risk aversion and requiring higher risk-taking incentives (Berger, Ofek, and Yermack (1997)); we have no a priori expectation for the sign on this variable. The Delta regression (3) includes the number of years that the current CEO has held his/her position (Tenure). Prior studies have shown that

\footnotetext{
${ }^{11}$ We estimated several alternative versions of the model (1), (2) and (3) that used different right-hand side identifications schemes. For example, in one of these schemes we added a proxy for Monitoring Cost to (2) and retained Salary in (1). Although our main tests of interest were robust to these and other changes in specification, these alternative models did not always pass statistical tests of identification. The results from these alternative regression specifications are available upon request; given that our tables already contain results from 90 separate regressions, we chose not to report the alternative specification results in order to conserve space.

${ }^{12}$ The EconCond variable is defined differently across the ten versions of our model, but is always constructed from one of the following three different state-level data sources: the Federal Reserve Bank of Philadelphia's Coincident Index of economic conditions for each state; the per-capita income for each state; and the payroll employment percentage for each state. Details available upon request.
} 
compensation committees are more likely to provide CEOs with high-delta contracts when the approach of CEO retirement creates horizon problems (Core and Guay (1999)). A vector of year dummies (Year) is included in all three equations.

In order to simplify our discussion of the expected signs on the Policy, Vega, and Delta coefficients in our model, we make the following reasonable presumptions: (a) bank risk is increasing in each of our Policy measures, (b) CEO risk-taking incentives are increasing in Vega, and (c) CEO risk-taking incentives are decreasing in Delta. The first presumption merely requires that both CEOs and bank boards believed the policy in question to be risk-increasing at the time it was implemented. The second presumption is not controversial. The third presumption arguably holds as a first principle, although as discussed above theoretical exceptions exist.

\section{A. Policy equation}

We use ten different definitions of the Policy variable to estimate the model: seven are narrow business policy variables commonly associated with relatively risky investment choices by banks, and three are broad market measures that capture the overall riskiness of banks' policies. Noninterest is total noninterest income and Noninterest Less is total noninterest income less fees from traditional fiduciary and depositor service activities; each measure is scaled by net operating income (i.e., noninterest income + interest income - interest expense). ${ }^{13}$ Based on the findings in the extant literature on noninterest income (e.g., DeYoung and Roland (2001), Stiroh

13 More detailed data on banks' noninterest income from nontraditional banking activities such as loan securitization, loan servicing, investment banking, brokerage, trading, venture capital, and insurance underwriting, or detailed data on banks’ derivatives holdings, did not become available until 2001. 
(2006), Elysiani and Wang (2008)), and assuming that bank managers during our sample period understood the risks embedded in these activities, we expect noninterest income to be a riskincreasing activity on average and thus positively related to Vega in equation (1).

Commercial, Commercial RE, and Mortgage are, respectively, commercial and industrial loans, commercial real estate loans, and 1-to-4 family mortgage loans scaled by bank assets. These three categories of loans have been linked to high levels of risk at banks—commercial loans traditionally have the highest default rates, commercial real estate loan defaults tend to spike during recessions, and mortgage defaults are at the root of the current financial crisiswhich suggests a positive association with Vega in equation (1). However, during our sample period large banks increasingly shifted credit risk off their balance sheets and onto their income statements via securitization and other methods (Stiroh (2004a, 2004b, and 2006)) which, depending on the extent of this risk shifting, could offset or even reverse the expected positive relationship. We measure the overall riskiness of the loans banks hold on-balance sheet with annual provisions for loan and lease losses (Provisions) scaled by total assets, and expect a positive association with Vega in equation (1). ${ }^{14}$

Losses in mortgage-backed securities investments were a central element in the financial and banking crisis of 2007-2009. Private MBS is the fair value of private mortgage securitizations held on-balance sheet, scaled by assets. (We get nearly identical results using the amortized book values of these investments.) Private MBS are backed by pools of sub-prime,

\footnotetext{
${ }^{14}$ All measures of loan quality derived from bank financial statements are flawed. We choose loan loss provisions because it reflects expected loan losses on recent loan investment decisions (compared with the allocation for loan losses, which includes expected losses for both recent and past loan investment decisions) and because it is more of an ex ante measure of risk (compared with loan charge-offs, which is a pure ex post measure of risk).
} 
Alt-A, jumbo, or other non-conforming mortgages, and as such they were known to be at least somewhat riskier investments than agency MBS (i.e., those issued by Fannie Mae, Freddie Mac, or Ginnie Mae) that are backed by conforming mortgages. ${ }^{15}$ If bank managers understood that these investments entailed large amounts of credit risk, then we expect investments in private MBS products to be positively related to Vega in equation (1).

In addition to these seven narrow measures of business policy, we also include three broad measures of market risk measures which might reflect the overall riskiness of banks' business policies. Total Risk is the standard deviation of daily stock returns over the year in question, Systematic Risk is the market returns slope coefficient (beta) estimated from a threefactor model (market return, yield on 3-month Treasuries, 2-year to 10-year yield spread on Treasuries), and Idiosyncratic Risk is the standard deviation of the residuals from the market model. ${ }^{16}$ Return volatility can be driven by either idiosyncratic or systematic events, we expect all three market risk measures to be positively related to Vega in equation (1). ${ }^{17}$

Given that the compensation literature (discussed above) provides ambiguous theoretical predictions about the relationship between delta and CEO risk-taking incentives, our expectations for the sign on the Delta coefficient in equation (1) are not as strong as those just stated for Vega. Nonetheless, based on our maintained assumption (c), we expect the coefficient

\footnotetext{
${ }^{15}$ Conforming mortgages have small principal amounts and loan-to-value ratio no more than $80 \%$ (or carry private mortgage insurance). A third category of mortgage-backed security is the so-called structured MBS, which is essentially an MBS that is backed by a pool of other MBSs. Structured MBS contracts are idiosyncraticdepending on the terms of the contract, investors are exposed to various amounts of credit risk and/or prepayment risk - and we exclude these investments from our study because they are held by a relatively small percentage of the banks in our sample.

${ }^{16}$ All of the results on our main tests were robust to using either a one-factor or two-factor market model.

${ }^{17}$ For example, Meulbroek (2001) and Duan and Wei (2005) find that the value of executive stock options increases with systematic risk after controlling for total risk.
} 
on Delta to be negative in all ten specification of equation (1), just the opposite of our expected positive coefficients on Vega in those regressions.

We note that our Policy variables focus exclusively on banks' business policy (investment) decisions, and that we do not explore banks' financial policy decisions. At depository intermediaries, the type and duration of liabilities are determined in large part by the type and duration of assets; that is, the investment decision and the financing decision are clearly not independent. At large banks like those in our data, liability mix tends to be determined by bank size (DeYoung, Hunter, and Udell (2004), Table A1) and by bank business policy choices (DeYoung and Yom (2008)) and, hence, is less likely to be a primary driver of risk. ${ }^{18}$ Focusing on just one type of policy decision also allows us to keep the model specification relatively simple and tractable.

\section{B. Vega and Delta equations}

A negative sign on Policy in equation (2) would indicate that bank boards provide fewer risk-taking incentives for CEOs (lower Vega) at banks with strategies that feature large investments in that particular (risky) business policy. A positive sign on Policy in equation (3) would indicate that bank boards attempt to align CEO more closely with shareholders (higher Delta) at banks with strategies that feature large investments in that particular (risky) business policy. Either or both of these findings would provide evidence that bank boards have been

\footnotetext{
${ }^{18}$ DeYoung and Yom (2008) find that, for large and medium-size U.S. commercial banks between 1990 and 2005, the cross-sectional variation in asset mix is substantially better at explaining the cross-sectional variation in liability mix than vice versa. They find little difference in the direction of this association for small banks, for which the deposit franchise is often an important driver of business policy. The authors also find that, regardless of the causal direction, the correlations between asset mix and liability mix become stronger as banks grow larger.
} 
using executive compensation incentives to limit or constrain risk taking. An opposite finding (a positive sign on Policy in equation (2) and/or a negative sign on Policy in equation (3)) would provide evidence that bank boards have been using executive compensation incentives to reinforce or support increased risk taking.

It is logical to think that bank boards will set CEO incentives holistically. A positive sign on Delta in equation (2) and/or a positive sign on Vega in equation (3) would indicate that bank boards use these incentive parameters in an offsetting fashion, for example, tempering high-vega incentives to increase the second moment of the stock price distribution with high-delta incentives to increase the first moment of the stock price distribution.

\section{Data}

Our sample is based on the intersection of the ExecuComp database and the Federal Reserve Y-9C database in 1994 through 2006. ExecuComp reports top executive compensation information extracted from the annual proxy statements for large, publicly traded U.S. corporations; we estimate our key variables Vega and Delta from these data. The Y-9Cs report quarterly financial statement data for large U.S. bank holding companies; we extract most of our Policy variables and control variables from the cumulative year-end December 31 reports. We start out with 141 commercial banking companies (SIC code 6020) that appear in ExecuComp during any of the years of our sample period, which generates a total of 1,057 bank-year observations. A relatively small number of observations are lost when we merge the two databases, lag some of the variables by one year, and estimate Vega and Delta. As shown in Table I, our final sample includes 881 bank-year observations of 134 different banks run by 200 
different CEOs between 1994 and 2006. We augmented these data with bank stock prices from the Center for Research in Securities Prices (CRSP) database, macroeconomic conditions data from the Federal Reserve Bank of Philadelphia, and interest rate data from the Federal Reserve Board.

\section{[Insert Table I about here]}

Table II presents summary statistics for the variables in our model. To reduce the influence of extreme values, the distributions of all variables are winsorized at the $1^{\text {st }}$ and $99^{\text {th }}$ percentiles of their sample distributions. Following Core and Guay (2002), we use the "one-year approximation” method to generate annual estimates of Vega and Delta. ${ }^{19}$ Vega has a mean (median) of $\$ 179,978(\$ 63,334)$, and Delta has a mean (median) of $\$ 754,592(\$ 361,383)$. In other words, the typical bank CEO enjoys an increase of \$63,334 in his/her equity portfolio for a 0.01 increase in stock return volatility, and an increase of $\$ 361,383$ for a $1 \%$ increase in stock price. The average CEO in the sample has about 9 years of tenure in the position and earns \$5.53 million in total annual compensation-approximately \$841,000 in salary, \$1.16 million in bonus, $\$ 2.00$ million in option grants, and $\$ \mathbf{8 2 5 , 0 0 0}$ in restricted stock. The sample banks are substantially larger than the typical U.S. commercial bank-mean (median) Assets is approximately \$66 billion (\$20 billion) measured in 2006 dollars_-and with average Noninterest of 36\% rely far more on fee-generating activities for income than the typical U.S. bank. The

\footnotetext{
${ }^{19}$ We value CEO stock options using the Black-Scholes (1973) model modified by Merton (1973) to account for dividends payouts, based on data from only the current year's proxy statement or annual report. Vega is the partial derivative of the option value with respect to stock-return volatility, multiplied by 0.01 times the number of options. Delta equals delta from options plus delta from stock holdings: delta from options is the partial derivative of the option value with respect to stock price, multiplied by $1 \%$ of the current stock price times the number of options; delta from stock holdings is simply the product of $1 \%$ of the current stock price and the number of shares.
} 
typical loan portfolio is relatively balanced between Commercial, Commercial RE, and Mortgage loans (about 14\%, 15\%, and 17\% of assets on average). Although Private MBS holdings are small on average, the top quartile of banks invest heavily in these assets. Provisions for loan losses are low_-less than $1 \%$ on average_-reflecting the relatively good banking climate during most of the years in our sample, but the standard deviation is relatively large.

[Insert Table II about here]

Table III, Panel A reports correlations between the ten Policy variables, the overall market risk measures (Total Risk, Systematic Risk, Idiosyncratic Risk), and the CEO incentive variables InVega and InDelta. ${ }^{20}$ Consistent with our expectations, fee-based income, investments in commercial loans and private MBS, and expected loan write-offs are all positively correlated with market risk, with the fee income measures more closely associated with systematic risk (DeYoung and Roland (2001), Choi, DeYoung, and Hasan (2006), Clark, Dick, Hirtle, Stiroh, and Williams (2007)) and the portfolio investment measures associated more closely with idiosyncratic risk. Despite their historical links to episodes of widespread bank failure, both commercial real estate loans and 1-to-4 family mortgage loans are negatively correlated with market risk. This likely reflects the relatively stable and predictable cash flows generated by these lines of business except during real estate downturns, combined with the fact that, prior to the 2007-2009 recession, real estate downturns had been regional phenomena and hence large banks could expect to diversify away much of the credit risk associated with these loans. ${ }^{21}$

\footnotetext{
${ }^{20}$ The table display Pearson correlations. Results are similar for Spearman correlations.

${ }^{21}$ This is in contrast to small banks that hold non-diversified portfolios of local commercial real estate loans which, as a result, historically comprise the largest percentage of bank insolvencies.
} 


\section{[Insert Table III about here]}

Although high-vega and high-delta compensation theoretically impart very different incentives on CEOs, InVega and InDelta have identical qualitative correlations with each of the ten Policy variables. Fee income, loan provisions, MBS holdings, and systematic risk are positively correlated with both of the CEO incentive measures, while commercial real estate loans, mortgage loans, and idiosyncratic risk are negatively correlated with both of the CEO incentive measures. These correlation patterns suggest that, when bank boards embed strong wealth incentives in CEO compensation packages, they tend to include both high-vega and highdelta incentives together. Of course, these patterns come from simple bivariate tests, so it is possible that one or more outside variables not controlled for in these tests are driving the observed patterns. Moreover, these simple statistical tests shed little light on the motivations of bank compensation committees.

Our main test variables exhibit a considerable amount of autocorrelation as well. By definition, bank business policies cannot change much from year-to-year: charting a business strategy requires fixed investments in expertise, location, inter-firm contracting, marketing, and customer relationships. The incentives embedded in CEO contracts should exhibit similar inertia: once CEOs have had a few years of tenure they will have accumulated large portfolios of stock and options, and annual increments to those portfolios will not alter the values of Delta and Vega much at the margin. ${ }^{22}$ As shown in Table III, Panel B, the average annual autocorrelation coefficients for Vega, Delta and six of the ten Policy variables indicate

${ }^{22}$ Ofek and Yermak (2000) show that equity compensation is a more effective tool when CEOs have low equity stakes. 
substantial persistence, ranging between 0.51 and 0.72 for CEOs with five or more years at their banks. Predictably, Provisions, Private MBS and NoninterestLess all exhibit less persistence (ranging between 0.38 and 0.49); loan quality varies with the business cycle, while both Private MBS and NoninterestLess were relatively new product lines that many banks were still working into their business strategies during our sample period. Only Systematic Risk exhibits little persistence over time.

\section{Model estimation and results}

Repeated and non-trivial changes in the corporate governance environments of our sample banks influence the manner in which we estimate our model. Our 1994-2006 data includes 134 different banking companies, although only 3 of these firms existed in all 13 years of the data with the same CEO. Collectively, these 134 banks employed 200 different CEOs during the sample period, and 61 of these 134 banks made at least one acquisition during the sample period that increased asset size by $25 \%$ or greater. For the 51 CEO changes for which we have complete compensation information, the average incoming CEO’s Delta was $10.9 \%$ lower than the average outgoing CEO's Delta, consistent with a change in governance in which new CEOs have different incentives than long-time CEOs. (The change in Vega around CEO changes was non-significant.) For the 22 largest and most acquisitive banks in our sample (i.e., banks with assets of at least $\$ 50$ billion that increased their size by at least $25 \%$ via acquisition in one year), Vega was $14.4 \%$ higher in the year of the acquisition relative to the year prior to the acquisition, consistent with a change in governance in which CEOs of large/growing banks face 
different incentives than other CEOs. (The change in Delta around these acquisitions was nonsignificant.)

These complications, combined with the relative bank-level inertia in Policy, Vega, and Delta discussed above, rule out a standard fixed-bank effects panel estimation approach. We apply three alternative treatments to the panel data. ${ }^{23}$ In the first approach we simply pool the unbalanced data panel. In the second approach we impose a 3-lag Newey-West autocorrelation structure at the CEO-level. The third (and our preferred) approach combines the first two approaches, pooling the data for CEOs who engaged in major acquisitions during the sample period but imposing the 3-lag Newey-West structure for CEOs who did not. ${ }^{24}$ In all cases, we estimate the system of equations (1), (2) and (3) using standard two-stage general method of moments estimation with instrumental variables (IV/2SGMM). Each equation is estimated individually, using the full set of exogenous right-hand side variables from the three-equation system as instruments for the two right-hand side endogenous variables. The system is exactly identified in the mechanical sense that the number of exclusions equals the number of equations; as described above, we exclude Salary and Tenure from equation (1), EconCond and Tenure from equation (2), and EconCond and Salary from equation (3).

\footnotetext{
${ }^{23}$ We also performed Fama-McBeth estimation (results not displayed, available upon request). The signs and magnitudes of the test coefficients are highly robust to this approach, but the small number of annual cross-sections in our data ( $T=13)$ make statistical inference difficult.

${ }^{24}$ We choose 3 lags for the Newey-West autocorrelation structure based on the distribution of the CEO tenure variable. Of the 202 chief executives at our sample banks, 170 ran their banks for 7 years or less. According to Petersen (2009, ft. 18), in the standard application of Newey-West a lag length of $M$ implies that one allows a correlation between the error terms of observations $t$ and $t-k$, where $\mathrm{k}$ runs from $-M$ to $M$. Thus, if we use 3 lags in Newey-West estimation, the autocorrelation structure completely covers $84 \%$ of the CEOs in our sample.
} 
We estimate 90 different versions of the model: ten different Policy variables, three different panel data treatments, three different model specifications/sub-samples. This generates a large volume of results, so to conserve space we report only the estimated coefficients for the Policy, InVega, and InDelta variables in Table IV (full sample), Table V (sub-sample that excludes the largest banks) and Table VI (full sample, testing for post-1999 effects). However, we do display the complete results for one full-sample version of the model (in which Policy = Systematic Risk) in Appendix Table A-II. The control variable coefficients and the diagnostic test results displayed there are reasonably representative of those obtained for the other Policy specifications (not shown here, but available upon request). As can be seen in Table A-II, system under-identification is rejected at high levels of significance for all the equations.

One must be careful when interpreting the estimated coefficients in the tables below. The coefficients largely capture cross-sectional variation in the data, not inter-temporal reactions within given firms. For example, a negative coefficient on Commercial in equation (2) would indicate that boards at banks with high concentrations of business lending relative to average industry levels of business lending tend to set lower than average pay-risk incentives (Vega) for their CEOs.

\section{A. Basic model}

The estimates displayed in Table IV strongly infer that banks' business policy choices and risk profiles were influenced by CEO wealth incentives between 1994 and 2006. In equation (1), high-vega compensation is associated with statistically significant increases in systematic and idiosyncratic risk, noninterest income, investment in private mortgage-backed securities, and 
loan portfolio credit risk - all of which are risk-increasing activities or indicators. Some of these increases are economically substantial. At the means of the data, a $10 \%$ increase in Vega is associated with a $2.0 \%$ increase in Idiosyncratic Risk, a $2.8 \%$ increase in Noninterest, a $3.1 \%$ increase in Systematic Risk, a 3.5\% increase in NoninterestLess, a 6.7\% increase in Provisions, and a $21.9 \%$ increase in Private $M B S{ }^{25}$ (The last of these estimates is clearly too large: Since about one-in-three observations of Private MBS are zeros, we re-estimated using Tobit-IV techniques and found a smaller yet still substantial $10.3 \%$ increase in Private MBS for a $10 \%$ increase in Vega. Results available upon request.) Not all of the Policy variables increased with Vega: a 10\% increase in Vega is associated with statistically significant $2.1 \%$ and $3.2 \%$ decreases, respectively, in Mortgage and Commercial RE. Collectively, these results infer that risk-seeking bank management shifts away from traditional portfolio lending and toward less traditional investment and off-balance sheet activities.

[Insert Table IV about here]

High-delta compensation affects business policy less often and somewhat less substantially. A $10 \%$ increase in Delta is associated with statistically significant decreases in risk—a 3.3\% decrease in NoninterestLess, a 2.9\% decrease in Noninterest, a 1.4\% decrease in Commercial, and a 1.1\% decrease in Systematic Risk—suggesting that bank boards provide offsetting pay-performance and pay-risk incentives for some activities. Similarly, a $10 \%$ increase in Delta is associated with statistically significant $8.1 \%$ and $2.8 \%$ increases,

\footnotetext{
${ }^{25}$ An example of these calculations: Given the semi-log regression specification, the estimated coefficient 0.286 is interpreted as the unit change in Systematic Risk associated with the percent change in Vega. Thus, $0.286 * 0.10 / 0.909=0.03146=3.1 \%$ gives the result, where 0.909 is the sample mean of Systematic Risk.
} 
respectively, in Private MBS and Commercial RE. (Note, however, that the Private MBS result becomes statistically non-significant in IV-Tobit estimation.)

There is a sensible symmetry in these results. CEOs with high pay-performance incentives (high-delta banks) tend to expand investment in lower risk activities and away from activities less well understood by investors. Within their loan portfolios, high-delta banks reduce their exposure to systematic risk by substituting commercial real estate loans for general (nonreal estate) business loans; outside their loan portfolio, high-delta banks generate smaller portions of their income from difficult-to-value noninterest activities (Elysiani and Wang (2008)), which also tends to reduce their exposure to systematic risk. Thus, the results suggest that high pay-performance sensitivity creates incentives for bank executives to run relatively traditional banking models. In contrast, CEOs with high pay-risk incentives (high-vega banks) choose policies more consistent with modern transactions banking models: more reliant on noninterest income and the systematic risk that comes with it (Clark, Dick, Hirtle, Stiroh, and Williams (2007)) and less reliant on traditional portfolio lending. Also note that the strong positive relationship between InVega and InAssets in Table A-II (a result that obtains in all estimations of the InVega equation) is consistent with the large size required by the transactions banking model.

We find less evidence that bank boards take existing bank business policies into account when setting CEO wealth incentives. In the case of Vega, interpreting this scant evidence is straightforward. The Policy variable carries a statistically significant coefficient in equation (2) only twice-for Idiosyncratic Risk and Total Risk — and in both cases the coefficient is negative. 
This suggests that compensation committees at banks with high (low) levels of non-systematic risk attempted to constrain (encourage) further non-systematic risk taking by giving their CEOs relatively low-vega (high-vega) compensation. We find no statistically significant evidence that individual lines of business were important determinants of Vega in equation (2). The results are quite different for Delta. The Policy variables carry statistically significant coefficients in equation (3) only twice—-for Noninterest and NoninterestLess—and in each case the coefficient is negative. Why would compensation committees at banks with the highest levels of feegenerating activities impose low pay-performance sensitivity on their CEOs, i.e., potentially weakening CEO alignment with shareholders and/or reducing CEO risk aversion? There are two diametrically possible interpretations. First, during much of our sample period many banking experts mistakenly believed that expanding into fee-based banking was risk-reducing (DeYoung and Roland (2001) and hence boards may have been unworried about the risks that we now know are associated with these lines of business. Second, compensation committees at transactions banks (i.e., high amounts of noninterest income) may have offered low-delta contracts to encourage further risk taking. The tests reported below in Table VII help us differentiate between these two possibilities.

The most consistent result in equations (2) and (3) is the positive and statistically significant coefficient on InVega in the InDelta regressions. This is consistent with our observation above from Table III, that is, when banks embed strong wealth incentives in their CEO compensation packages they tend to include both high-vega and high-delta incentives. But we note that the symmetric result (a positive coefficient on InDelta in the InVega regressions) 
does not obtain. Taken together, these results suggest that compensation committees at the banks that we study tended to use high-delta contracts to moderate potential CEO risk-taking induced by high vegas, but did not tend to use high-vega contracts to moderate potential CEO riskaversion induced by high deltas.

We note that the size distribution of the banks in our sample is skewed heavily to the right: the median bank has assets of $\$ 20$ billion, the mean bank has assets of $\$ 66$ billion, and the largest banks in the sample have over $\$ 1$ trillion in assets. It is natural to wonder whether the different regulatory treatment received by these "too-big-to-fail” banks alters their risk-taking decisions and corporate governance environments. To test whether our results are driven by outlying behaviors at large banks, we re-estimated the models after excluding bank-year observations in which banking assets exceeded \$100 billion (2006 dollars). The resulting subsample contained 747 annual observations (134 fewer than in Table IV) for 124 different banking companies (10 fewer than in Table IV). The results of this re-estimation (not shown, available upon request) are qualitatively, and for the most part quantitatively, no different from those in Table IV.

\section{B. Before and after deregulation}

As shown in Figure 2, the incentive structure of bank CEO compensation diverged from the incentive structure in non-bank CEO compensation after 1999. Bank-CEO vega increased markedly, suggesting that bank boards were encouraging executives to exploit the new investment opportunities made possible by Gramm-Leach-Bliley Act and perhaps exacerbated by the boom in securitized mortgage lending markets. To test whether this apparent change in risk- 
taking incentives influenced bank business policies, we added a Post1999 dummy to the righthand side of all three equations in our model, and also interacted with the right-hand side Policy, InVega, and InDelta variables. The results of this more flexible specification, which we estimated using two-stage least squares (2SLS) techniques on pooled time series-cross section data, are displayed in Table V. ${ }^{26}$ The estimations reveal three general post-1999 patterns: bank business policies became more sensitive to the contractual risk-taking incentives of the CEO; incentives were put in place to constrain risk-taking at high-risk banks; and incentives were used to encourage CEOs to exploit new growth opportunities.

[Insert Table V about here]

Column [1] in Table V shows that five of the ten business policies—Idiosyncratic Risk, Total Risk, Noninterest, NoninterestLess, and Provisions - became both more positively associated with vega and more negatively associated with delta after 1999. This increased sensitivity of policy choices to compensation incentives arguably indicates that bank boards either became better able to influence, or grew more serious about influencing, the decisions of their CEOs. In either case, these results suggests that bank boards had increased control over CEO decision-making, and thus over the riskiness of their banks, after deregulation. Column [2] shows that CEOs choosing high levels of Private MBS, Idiosyncratic Risk and/or Total Risk became more likely to receive low-vega compensation after 1999, evidence that bank boards were attempting to use pay incentives to constrain risk-taking at banks that held or purchased

\footnotetext{
${ }^{26}$ These simple pooled time series-cross section estimates are most comparable to those displayed in columns [1], [4], and [7] in Table IV. Adding the interaction terms doubled the number of endogenous variables in the equation system, and given a lack of good additional instruments this precluded us from performing IV/2SGMM estimation. We performed these 2SLS estimations manually, which precluded Newey-West estimation.
} 
large amounts of mortgage-backed securities or otherwise engaged in activities that generated large amounts of market risk. In contrast, CEOs choosing high levels of Commercial, Mortgage and Provisions became more likely to receive high-vega compensation after 1999; we interpret this as encouragement for CEOs at banks with traditional on-balance sheet lending strategies (which would yield relatively high levels of loan loss provisions-to-assets, ceteris paribus) to take additional off-balance sheet risks, perhaps by pursuing new growth opportunities provided by deregulation. Column [3] indicates that compensation committees at high-vega banks became more likely to moderate those risk-taking incentives after 1999 by choosing high deltas. In addition, the results here show that the negative relationship between Delta and the noninterest income variables found in Table IV is largely a post-1999 phenomenon, consistent with the argument advanced above that bank boards were encouraging their CEOs to take advantage of nontraditional fee-based growth opportunities.

\section{Summary, Discussion, and Conclusions}

The huge losses suffered by large U.S. financial institutions that created and invested in risky mortgage-backed securities—and the equally huge government equity injections, debt guarantees, and liquidity creation aimed at keeping these firms afloat and financial markets functioning - have raised the ire of taxpayers and those who represent them. Public officials have responded with a variety of schemes to limit and/or claw back the pay of the financial executives who "got us into this mess." Although a substantial portion of the government loans and capital injections are likely to be paid back, and while the most extreme ex post facto 
sanctions on employee pay and bonuses may not withstand legal scrutiny, some of the proposed interventions have come to pass. This episode has increased the likelihood of a more permanent role for government in monitoring and determining executive pay in publicly traded companies.

Underlying these efforts to control executive pay is the conventional wisdom that corporate risk-taking can be controlled by inserting the proper incentives into executive compensation contracts. We test for evidence to support this conventional wisdom at large U.S. commercial banking companies between 1994 and 2006. We examine whether and how the terms of CEO compensation contracts at these firms influenced the business policies of these firms, and we simultaneously test whether and how bank boards set the terms of CEO compensation conditional on the business policies currently under executed at their banks. We find strong evidence that bank CEOs respond to contractual risk-taking incentives by taking more risk; systematic evidence that bank boards altered CEO compensation to encourage executives to pursue new growth opportunities; and more limited evidence that bank boards set CEO incentives in a manner designed to moderate excessive risk-taking.

On average during our sample period, banks in which CEOs had high pay-risk sensitivity (high-vega banks) generated a larger percentage of their incomes from noninterest activities, invested a larger percentage of their assets in private (i.e., subprime or otherwise nonconforming) mortgage securitizations, invested a smaller percentage of their assets in on-balance sheet loan portfolios, and took on greater credit risk and greater market risk. CEO business policy decisions became more responsive to pay-risk sensitivity after 1999, when the GrammLeach-Bliley Act expanded commercial banks’ investment opportunity sets. Compensation 
committees also became more responsive to the risk profiles of their banks after 1999, setting CEO vega relatively lower at banks with high levels of market risk and/or concentrations of private mortgage-backed securities (i.e., constraining risk taking) and setting CEO vega relatively higher at banks with traditional portfolio-lending business strategies (i.e., encouraging investment in riskier, non-traditional activities). Throughout the entire sample period, and especially after 1999, bank boards balanced the risk-taking incentives of high CEO vegas by setting complementarily high values of CEO deltas, perhaps believing that closer alignment of executive and shareholder wealth might mitigate excessive CEO risk-taking responses.

We draw four broad conclusions from these findings. First, banking executives were aware to at least some extent of the risks associated with their investments in private issue MBS; our results linking high-vega CEOs to private MBS investments run contrary to the claim that banks were misled by over-optimistic ratings on MBS (although such claims may be valid for less sophisticated investors). ${ }^{27}$ Similarly, our results linking high-vega CEOs to noninterest income suggest that large bank executives had become, sometime during our 1994-2006 sample period, well aware of the increased risks associated with transactions banking business strategies. Second, banking executives respond in economically meaningful ways to the incentives present in their compensation contracts. While this lends some legitimacy to arguments for government intervention to limit contractual risk-taking incentives for executives at systemically important

\footnotetext{
${ }^{27}$ Internal rating agency emails from before the time the credit markets deteriorated, discovered and released publicly by U.S. congressional investigators, suggest that some rating agency employees suspected at the time that lax standards for rating structured credit products would produce negative results. (U.S. House of Representatives Committee on Government Oversight and Reform, 10-12-2008, "Committee Holds Hearings on the Credit Rating Agencies and the Financial Crisis,” http://oversight.house.gov/story.asp?ID=2250.)
} 
financial institutions, this is merely a necessary and not a sufficient condition for such policies. Evidence that intervention will be effective (i.e., lead to a net improvement in social welfare) is necessary as well. Moreover, nothing in this study supports such policies for banks that do not pose systemic risks. Third, government intervention to limit risk-taking incentives in financial executive compensation contracts could at best strengthen, and at worst interfere with, the compensation-based risk mitigation behaviors already being exhibited by bank boards that we detect here. The terms of optimal contract incentives are likely to vary substantially across firms and CEOs, while government prescriptions almost by necessity tend to be one-size-fits-all. Furthermore, the contractual incentives that we test here were designed by boards to mitigate principal-agent problems on the behalf of shareholders, while contractual incentives imposed via regulation are presumably aimed at providing public goods (i.e., financial market stability, fairness) and could work far differently. Fourth, putting aside populist arguments that executive compensation is too large in the absolute, as well as the argument that the Gramm-Leach-Bliley Act was a policy misstep, our evidence suggests that bank compensation committees acted efficiently, effectively, and prudentially in response to deregulation. Bank boards altered compensation incentives (higher vegas) in hopes that bank executives would take advantage of the new growth opportunities put in place by Congress. So-incented, CEOs exploited those opportunities, as evidenced by increased fee-based income from nontraditional activities. And it appears that bank boards attempted to moderate the risk-taking incentives embedded in highvega compensation by also including high-delta compensation in those same contracts. 
In interpreting our 1994-2006 findings, it is important to realize that bank managers were making their policy decisions conditional not only on the incentives structured into their compensation agreements, but also conditional on their beliefs regarding the risk-return tradeoffs associated with their various policy options. The 2007-2009 financial crisis is likely to have changed managers' understanding of risks and returns in some lines of business. For example, the housing downturn revealed that many mortgage-backed securities were far riskier than suggested by either their third-party ratings or their contractual yields; managers' beliefs about the risk-return tradeoffs inherent in MBS are likely to have changed post-downturn. Thus, our 1994-2006 tests reflect bank managers’ pre-crisis beliefs about the risk-return qualities of MBS, and may only imperfectly capture how their business policy choices will react to contractual risktaking incentives in a more informed post-crisis environment. Similarly, our estimates are based on the incomplete pre-crisis understanding of these risk-return tradeoffs by bank boards and compensation committees. Thus, one must be careful when drawing inferences about optimal post-crisis policy based on our pre-crisis results. Proposals to foster macroeconomic stability by rolling back banking powers may be misguided, because informed post-crisis managers will arguably be better able to implement those powers effectively. And proposals to constrain risktaking by limiting the ability of bank boards to set the terms of executive compensation may also be misguided, because informed post-crisis boards will arguably be better able to determine efficient incentives.

Finally, we note that none of these conclusions are meant to extend to non-banking firms. Commercial banks are subject to supervisory monitoring that, if not explicitly, implicitly creates 
extra pressure for boards to mitigate risk-taking managerial behaviors. Moreover, the level and types of risk taken by bank executives, and endorsed by bank compensation committees, during the 1990s and 2000s are to some large extent special to the newness of the transactions banking business model and the incomplete understanding of the risks inherent in that model and the products it created. 


\section{References}

Adams, R., and H. Mehran, 2003, Is Corporate Governance Different for Bank Holding Companies?, Federal Reserve Bank of New York Economic Policy Review 9, 123-142.

Berger, Phillip G., Eli Ofek, and David L. Yermack, 1997, Managerial entrenchment and capital structure decisions, Journal of Finance 52, 1411-1438.

Black, Fischer, and Myron Scholes, 1973, The pricing of options and corporate liabilities, Journal of Political Economy 81, 637-654.

Chen, Carl R., Thomas L. Steiner, and Ann M. Whyte, 2006, Does stock option-based executive compensation induce risk-taking? An analysis of the banking industry, Journal of Banking and Finance 30, 915-945.

Choi, Sungho, Robert DeYoung, and Iftekhar Hasan, 2006, Risk, Return, and Noninterest Income at Commercial Banks: Cross-Country Evidence, Unpublished working paper, Rensselaer Polytechnic Institute.

Chhaochharia, Vidhi, and Yaniv Grinstein, 2009, CEO Compensation and Board Structure, Journal of Finance 64, 231-261.

Clark, Timothy, Astrid A. Dick, Beverly Hirtle, Kevin J. Stiroh, and Robard Williams, 2007, The role of retail banking in the U.S. banking industry: risk, return, and industry structure, Economic Policy Review - Federal Reserve Bank of New York 13, 39-56.

Coles, Jeffrey L., Naveen D. Daniel, and Lalitha Naveen, 2006, Managerial incentives and risktaking, Journal of Financial Economics 79, 431-468.

Core, John, and Wayne Guay, 1999, The use of equity grants to manage optimal equity incentive levels, Journal of Accounting and Economics 28, 151-184.

Core, John, and Wayne Guay, 2002, Estimating the value of employee stock option portfolios and their sensitivities to price and volatility, Journal of Accounting Research 40, 613630.

DeYoung, Robert, William C. Hunter, and Gregory F. Udell, 2004, The Past, Present, and Probable Future for Community Banks, Journal of Financial Services Research 25, 85133. 
DeYoung, Robert, and Karin P. Roland, 2001, Product mix and earnings volatility at commercial banks: evidence from a degree of total leverage model, Journal of Financial Intermediation 10, 54-84.

DeYoung, Robert, and Tara Rice, 2004, Noninterest income and financial performance at U.S. commercial banks, The Financial Review 39, 101-127.

DeYoung, Robert, and Chiwon Yom, 2008, On the Independence of Assets and Liabilities: Evidence from U.S. Commercial Banks, Journal of Financial Stability 4, 275-303.

Duan, Jin-Chuan, and Jason Wei, 2005, Executive stock options and incentive effects due to systematic risk, Journal of Banking and Finance 29, 1185-1211.

Elysiani, Elyas, and Yong Wang, 2008, Non-Interest Income Diversification and Information Asymmetry of Bank Holding Companies, Working paper, Temple University.

Fahlenbrach, Rüdiger, and René M. Stulz, 2009, Bank CEO Incentives and the Credit Crisis, Working paper, NBER.

Ge’Czy, Christopher C., Bernadette A. Minton, and Catherine M. Schrand, 2007, Taking A View: Corporate Speculation, Governance, And Compensation, Journal of Finance 62, 2405-2443.

Gritsch, Martin, and Tricia C. Snyder, 2005, The impact of current tax policy on CEO stock option compensation: a quantile analysis, Academy of Accounting and Financial Studies Journal, September.

Guay, Wayne, 1999, The sensitivity of CEO wealth to equity risk: an analysis of the magnitude and determinants, Journal of Financial Economics 53, 43-71.

Houston, Joel F., and Christopher James, 1995, CEO compensation and bank risk: is compensation in banking structured to promote risk taking, Journal of Monetary Economics 36, 405-431.

Hubbard, R. G., and Darius Palia, 1995, Executive pay and performance: evidence from the U.S. banking industry, Journal of Financial Economics 39, 105-130.

Hughes, Joseph P., William W. Lang, Loretta J. Mester, Choon-Geol Moon, 1996, Efficient banking under interstate branching, Journal of Money, Credit, and Banking 28, 10451071. 
Jensen, Michael C., and William H. Meckling, 1976, Theory of the firm: managerial behavior, agency costs, and ownership structure, Journal of Financial Economics 3, 305-360.

John, Teresa A., and Kose John, 1993, Top-management compensation and capital structure, Journal of Finance 48, 949-974.

Knopf, John D., Jouahn Nam, and John H. Thornton Jr., 2002, The volatility and price sensitivities of managerial stock option portfolios and corporate hedging, Journal of Finance 57, 801-814.

Macey, Jonathan R., and Maureen O’Hara, 2003, The Corporate Governance of Banks, Federal Reserve Bank of New York Economic Policy Review 9, 91-107.

McConnell, John J., and Henri Servaes, 1990, Additional evidence on equity ownership and corporate value, Journal of Financial Economics 27, 595-612.

Merton, Robert C., 1973, Theory of rational option pricing, Bell Journal of Economics and Management Science 4, 141-183.

Meulbroek, Lisa K., 2001, The efficiency of equity-linked compensation: understanding the full cost of awarding executive stock options, Financial Management 30, 5-44.

Minnick, Kristina, Haluk Unal, and Liu Yang, 2009, Pay for Performance? CEO Compensation and Acquirer Returns in BHCs, Working paper, UCLA.

Morck, Randall, Andrei Shleifer, and Robert Vishny, 1988, Management ownership and market valuation: an empirical analysis, Journal of Financial Economics 20, 293-315.

Nam, Jouahn, Richard E. Ottoo, and John H. Thornton Jr., 2003, The effect of managerial incentives to bear risk on corporate investment and $\mathrm{R} \& \mathrm{D}$ investment, The Financial Review 38, 77-101.

Ofek, Eli, and David Yermack, 2000, Taking Stock: Equity-Based Compensation and the Evolution of Managerial Ownership, Journal of Finance 55, 1367-1384.

Petersen, Mitchell A., 2009, Estimating Standard Errors in Finance Panel Data Sets: Comparing Approaches, Review of Financial Studies 22, 435-480.

Rogers, Daniel A., 2002, Does executive portfolio structure affect risk management? CEO risktaking incentives and corporate derivative usage, Journal of Banking and Finance 26, 271-295. 
Rossi, Clifford V., 1998, Mortgage banking cost structure: resolving an enigma, Journal of Economics and Business 50, 219-234.

Smith, Clifford W., and Rene M. Stulz, 1985, The determinants of firms' hedging policies, Journal of Financial and Quantitative Analysis 20, 391-405.

Smith, Clifford W., and Ross L. Watts, 1992, The investment opportunity set and corporate financing, dividend, and compensation policies, Journal of Financial Economics 32, 263293.

Stein, Jeremy C., 2002, Information production and capital allocation: decentralized versus hierarchical firms, Journal of Finance 57, 1891-1921.

Stiroh, Kevin, 2004a, Do community banks benefit from diversification?, Journal of Financial Services Research 25, 135-160.

Stiroh, Kevin, 2004b, Diversification in banking: is noninterest income the answer?, Journal of Money, Credit, and Banking 36, 853-882.

Stiroh, Kevin, 2006, New evidence on the determinants of bank risk, Journal of Financial Service Research 30, 237-263. 


\section{Table I Data Structure}

This table provides data structure information for the sample of 881 observations from 1994 to 2006 .

Panel A: Number of observations by year

\begin{tabular}{c|c}
\hline Year & $\begin{array}{c}\text { No. of } \\
\text { Observations }\end{array}$ \\
\hline 1994 & 70 \\
1995 & 65 \\
1996 & 69 \\
1997 & 69 \\
1998 & 73 \\
1999 & 71 \\
2000 & 68 \\
2001 & 61 \\
2002 & 69 \\
2003 & 71 \\
2004 & 64 \\
2005 & 69 \\
2006 & 62 \\
\hline Total & 881 \\
\hline
\end{tabular}

Panel B: Number and distribution of banks and CEOs

\begin{tabular}{c|cccccc}
\hline & & \multicolumn{5}{c}{ number of years that banks or CEOs appear in the data sample } \\
\cline { 2 - 6 } & $\begin{array}{c}\text { Number of banks or CEOs } \\
\text { in the data sample }\end{array}$ & mean & $\begin{array}{c}\text { standard } \\
\text { deviation }\end{array}$ & $\begin{array}{c}\text { 25th } \\
\text { percentile }\end{array}$ & median & $\begin{array}{c}75 \text { th } \\
\text { percentile }\end{array}$ \\
\hline Banks & 134 & 6.577 & 4.172 & 3 & 6 & 10 \\
CEOs* & 200 & 4.405 & 3.033 & 2 & 4 & 6 \\
\hline
\end{tabular}

* 51 banks changed CEOs at least once during the sample period.

Panel C: Number and incidence of significant increases in bank size. (Significant increase $=\mathbf{2 5 \%}$ inflation-adjusted year-to-year increase in assets.)

a. Number of significant annual increases in asset size*

b. Number of annual observations for CEOs involved with significant increases

c. Mean years between significant increases for CEOs involved with significant increases (a /b)

* 61 banks experienced significant increases in asset size at least once during the sample period. 


\section{Table II Summary statistics}

This table provides summary statistics for measures of CEO compensation, bank policy, and bank characteristics for the sample of 881 observations from 1994 to 2006. All variable definitions are included in Appendix Table A-I.

\begin{tabular}{|c|c|c|c|c|c|c|}
\hline & $\begin{array}{l}\text { \# of } \\
\text { Obs }\end{array}$ & Mean & $\begin{array}{l}\text { Standard } \\
\text { Deviation }\end{array}$ & $\begin{array}{c}25 \text { th } \\
\text { Percentile }\end{array}$ & Median & $\begin{array}{c}75 \text { th } \\
\text { Percentile }\end{array}$ \\
\hline \multicolumn{7}{|l|}{ Endogenous variables } \\
\hline Vega (\$000s) & 881 & 179.978 & 283.304 & 26.006 & 63.334 & 197.797 \\
\hline InVega & 881 & 4.196 & 1.580 & 3.296 & 4.164 & 5.292 \\
\hline Delta (\$000s) & 881 & 754.592 & 1214.490 & 153.652 & 361.383 & 879.189 \\
\hline InDelta & 881 & 5.884 & 1.243 & 5.041 & 5.893 & 6.780 \\
\hline Total Risk & 881 & 0.017 & 0.006 & 0.013 & 0.016 & 0.021 \\
\hline Systematic Risk & 881 & 0.908 & 0.341 & 0.677 & 0.884 & 1.127 \\
\hline Idiosyncratic Risk & 881 & 0.015 & 0.006 & 0.011 & 0.013 & 0.017 \\
\hline Noninterest & 881 & 0.362 & 0.165 & 0.246 & 0.323 & 0.432 \\
\hline NoninterestLess & 881 & 0.207 & 0.140 & 0.113 & 0.168 & 0.251 \\
\hline Commercial & 881 & 0.144 & 0.077 & 0.092 & 0.137 & 0.185 \\
\hline Commercial RE & 881 & 0.149 & 0.102 & 0.077 & 0.129 & 0.205 \\
\hline Mortgage & 881 & 0.172 & 0.096 & 0.107 & 0.168 & 0.225 \\
\hline Provisions & 881 & 0.003 & 0.003 & 0.001 & 0.002 & 0.004 \\
\hline Private MBS & 880 & 0.016 & 0.034 & 0.000 & 0.001 & 0.016 \\
\hline \multicolumn{7}{|l|}{ Control variables } \\
\hline Assets (\$000s) & 881 & $65,777,623$ & $132,191,347$ & $7,369,412$ & $20,480,072$ & $57,283,876$ \\
\hline InAssets & 881 & 16.965 & 1.363 & 15.813 & 16.835 & 17.864 \\
\hline$M B$ & 881 & 2.413 & 0.969 & 1.720 & 2.181 & 2.857 \\
\hline $\ln M B$ & 881 & 1.191 & 0.262 & 1.001 & 1.157 & 1.350 \\
\hline Equity Ratio & 881 & 0.083 & 0.016 & 0.072 & 0.081 & 0.093 \\
\hline InSalary & 881 & 6.660 & 0.394 & 6.406 & 6.731 & 6.939 \\
\hline Tenure & 881 & 9.005 & 6.702 & 4.000 & 7.000 & 13.000 \\
\hline Coincident index & 881 & 134.627 & 15.169 & 122.812 & 136.397 & 144.882 \\
\hline Per capita income & 881 & 33.714 & 4.451 & 30.795 & 33.000 & 36.945 \\
\hline Payroll employment & 881 & 0.398 & 0.032 & 0.376 & 0.394 & 0.417 \\
\hline \multicolumn{7}{|c|}{ Addendum: Details of compensation } \\
\hline Total compensation (\$000s) & 878 & $5,525.440$ & $6,191.660$ & $1,734.690$ & $3,144.790$ & $6,712.100$ \\
\hline Salary (\$000s) & 881 & 840.532 & 330.813 & 604.396 & 836.936 & $1,030.930$ \\
\hline Bonus (\$000s) & 881 & 1,159.050 & $1,629.110$ & 246.914 & 560.000 & $1,348.310$ \\
\hline Option grants (\$000s) & 878 & $2,000.410$ & $3,104.360$ & 205.925 & 802.539 & $2,427.320$ \\
\hline Restricted stock grants ( $\$ 000$ s) & 881 & 825.407 & 2,112.990 & 0 & 0 & 656.211 \\
\hline
\end{tabular}




\section{Table III Data correlations}

This table presents Pearson correlation coefficients among compensation incentive, risk, and bank policy variables, and autocorrelation coefficients for bank policies for the sample of 881 observations from 1994 to 2006. Panel A reports Pearson correlation coefficients. Penal B reports average autocorrelation coefficients for CEO with 5 or more years at their banks. The average slope coefficients are estimated from the ordinary least squares regression Policy $(\mathrm{t})=\mathrm{a}+\mathrm{b} *$ Policy $(\mathrm{t}-1)$. All variable definitions are included in Appendix Table A-I.

\section{Panel A: Pearson correlations}

\begin{tabular}{lccccc}
\hline \multirow{2}{*}{ Policy variables } & \multirow{2}{*}{ Total Risk } & $\begin{array}{c}\text { Systematic } \\
\text { Risk }\end{array}$ & $\begin{array}{c}\text { Idiosyncratic } \\
\text { Risk }\end{array}$ & InVega & InDelta \\
\hline Noninterest & $0.095^{* * *}$ & $0.276^{* * *}$ & -0.004 & $0.435^{* * *}$ & $0.394^{* * *}$ \\
NoninterestLess & $0.116^{* * *}$ & $0.263^{* * *}$ & 0.030 & $0.405^{* * *}$ & $0.383^{* * *}$ \\
Commercial & $0.069^{* *}$ & 0.015 & $0.075^{* *}$ & 0.000 & -0.021 \\
Commercial RE & $-0.120^{* * *}$ & $-0.092^{* * *}$ & $-0.089^{* * *}$ & $-0.242^{* * *}$ & $-0.291^{* * *}$ \\
Mortgage & $-0.194^{* * *}$ & $-0.250^{* * *}$ & $-0.159^{* * *}$ & $-0.104^{* * *}$ & $-0.079^{* *}$ \\
Provisions & $0.288^{* * *}$ & $0.111^{* * *}$ & $0.214^{* * *}$ & $0.197^{* * *}$ & $0.189^{* * *}$ \\
Private MBS & $0.084^{* * *}$ & 0.041 & $0.085^{* * *}$ & $0.070^{* *}$ & $0.134^{* * *}$ \\
Total Risk & -- & -- & -- & 0.049 & 0.049 \\
Systematic Risk & -- & -- & -- & $0.268^{* * *}$ & $0.220^{* * *}$ \\
Idiosyncratic Risk & -- & -- & -- & $-0.085^{* * *}$ & -0.052 \\
\hline
\end{tabular}

Panel B: Average Autocorrelation Coefficients

\begin{tabular}{llc}
\hline & $N$ & Mean $b$ \\
\hline Vega & 65 & $0.7092^{* * *}$ \\
Delta & 65 & $0.6232^{* * *}$ \\
Noninterest & 65 & $0.6335^{* * *}$ \\
NoninterestLess & 65 & $0.4870^{* * *}$ \\
Commercial & 65 & $0.5935^{* * *}$ \\
Commercial RE & 65 & $0.7211^{* * *}$ \\
Mortgage & 65 & $0.5066^{* * *}$ \\
Provisions & 65 & $0.4478^{* * *}$ \\
Private MBS & 44 & $0.3818^{* * *}$ \\
Total Risk & 65 & $0.5217^{* * *}$ \\
Systematic Risk & 65 & $0.0987^{*}$ \\
Idiosyncratic Risk & 65 & $0.6475^{* * *}$ \\
\hline
\end{tabular}




\section{Table IV Two-stage Least Squares Results for the Full Sample}

This table displays selected two-stage least squares parameters from equations (1), (2) and (3). The parameters are estimated based on an unbalanced data panel of 881 annual observations for 134 different publicly traded U.S. banking companies from 1994 to 2006. Robust standard errors are reported in brackets. All variable definitions are included in Appendix Table A-I. The superscripts ***, **, and * indicate statistical significance at the $1 \%, 5 \%$, and $10 \%$ levels.

\begin{tabular}{|c|c|c|c|c|c|c|c|c|c|}
\hline $\begin{array}{l}\text { dependent } \\
\text { variable: }\end{array}$ & $\begin{array}{c}{[1]} \\
\text { Policy }\end{array}$ & $\begin{array}{c}{[2]} \\
\text { Policy }\end{array}$ & $\begin{array}{c}{[3]} \\
\text { Policy }\end{array}$ & $\begin{array}{c}{[4]} \\
\text { InVega }\end{array}$ & $\begin{array}{c}\text { [5] } \\
\text { InVega }\end{array}$ & $\begin{array}{c}\text { [6] } \\
\text { InVega }\end{array}$ & $\begin{array}{c}{[7]} \\
\text { InDelta }\end{array}$ & $\begin{array}{c}{[8]} \\
\text { InDelta }\end{array}$ & $\begin{array}{c}{[9]} \\
\text { InDelta }\end{array}$ \\
\hline $\begin{array}{l}\text { panel data } \\
\text { treatment: }\end{array}$ & pooled & $\begin{array}{c}\text { Newey- } \\
\text { West by } \\
\text { CEO }\end{array}$ & $\begin{array}{c}\text { Newey- } \\
\text { West by } \\
\text { CEO if no } \\
\text { large M\&A }\end{array}$ & pooled & $\begin{array}{c}\text { Newey- } \\
\text { West by } \\
\text { CEO }\end{array}$ & $\begin{array}{c}\text { Newey- } \\
\text { West by } \\
\text { CEO if no } \\
\text { large } M \& A \\
\end{array}$ & pooled & $\begin{array}{l}\text { Newey- } \\
\text { West by } \\
\text { CEO }\end{array}$ & $\begin{array}{c}\text { Newey- } \\
\text { West by } \\
\text { CEO if no } \\
\text { large M\&A }\end{array}$ \\
\hline \multirow[t]{2}{*}{ Systematic Risk } & & & & -3.396 & -3.396 & -3.396 & 1.193 & 1.193 & 1.193 \\
\hline & & & & [2.148] & {$[2.544]$} & {$[2.426]$} & [0.742] & [1.030] & [0.893] \\
\hline \multirow[t]{2}{*}{ lnVega } & $0.286 * * *$ & $0.286 * *$ & $0.286 * * *$ & & & & $0.481 * * *$ & $0.481 * *$ & $0.481 * * *$ \\
\hline & {$[0.085]$} & [0.122] & [0.105] & & & & [0.143] & {$[0.218]$} & {$[0.174]$} \\
\hline \multirow[t]{2}{*}{ InDelta } & $-0.100 * *$ & -0.100 & $-0.100 *$ & -0.429 & -0.429 & -0.429 & & & \\
\hline & [0.045] & {$[0.065]$} & [0.055] & {$[0.311]$} & [0.425] & [0.391] & & & \\
\hline \multirow[t]{2}{*}{ Idiosyncratic Risk } & & & & $-180.595 *$ & -180.595 & $-180.595^{*}$ & 81.395 & 81.395 & 81.395 \\
\hline & & & & [94.579] & [110.179] & [104.388] & [49.968] & [69.021] & [60.273] \\
\hline \multirow[t]{2}{*}{ InVega } & $0.003 * * *$ & $0.003^{*}$ & $0.003^{* *}$ & & & & $0.575^{* * *}$ & $0.575^{* * *}$ & $0.575 * * *$ \\
\hline & {$[0.001]$} & [0.001] & {$[0.001]$} & & & & [0.127] & {$[0.198]$} & {$[0.147]$} \\
\hline \multirow[t]{2}{*}{ InDelta } & $-0.001 *$ & -0.001 & -0.001 & -0.226 & -0.226 & -0.226 & & & \\
\hline & [0.001] & [0.001] & {$[0.001]$} & [0.206] & [0.302] & [0.272] & & & \\
\hline \multirow[t]{2}{*}{ Total Risk } & & & & $-210.156^{*}$ & $-210.156^{*}$ & $-210.156^{*}$ & 100.905 & 100.905 & 100.905 \\
\hline & & & & [109.316] & [127.664] & [120.320] & [62.359] & [85.648] & [74.768] \\
\hline \multirow[t]{2}{*}{ InVega } & $0.002 * *$ & 0.002 & 0.002 & & & & $0.602 * * *$ & $0.602 * * *$ & $0.602 * * *$ \\
\hline & {$[0.001]$} & [0.001] & [0.001] & & & & [0.128] & [0.201] & [0.148] \\
\hline \multirow[t]{2}{*}{ InDelta } & 0.000 & 0.000 & 0.000 & -0.165 & -0.165 & -0.165 & & & \\
\hline & {$[0.000]$} & {$[0.001]$} & [0.001] & [0.193] & [0.286] & {$[0.256]$} & & & \\
\hline \multirow[t]{2}{*}{ Noninterest } & & & & 1.231 & 1.231 & 1.231 & $-2.077 * *$ & -2.077 & $-2.077 *$ \\
\hline & & & & [1.175] & [1.780] & [1.687] & [0.925] & [1.298] & [1.183] \\
\hline \multirow[t]{2}{*}{ lnVega } & $0.102^{* * *}$ & $0.102^{*}$ & $0.102^{* *}$ & & & & $0.791 * * *$ & $0.791^{* * *}$ & $0.791 * * *$ \\
\hline & [0.038] & [0.060] & [0.048] & & & & [0.171] & [0.266] & {$[0.211]$} \\
\hline \multirow[t]{2}{*}{ InDelta } & $-0.106 * * *$ & $-0.106 * * *$ & $-0.106 * * *$ & 0.078 & 0.078 & 0.078 & & & \\
\hline & [0.022] & [0.033] & [0.029] & [0.248] & [0.379] & [0.354] & & & \\
\hline
\end{tabular}

(continued on next page) 


\begin{tabular}{|c|c|c|c|c|c|c|c|c|c|}
\hline $\begin{array}{l}\text { dependent } \\
\text { variable: }\end{array}$ & $\begin{array}{c}\text { [1] } \\
\text { Policy }\end{array}$ & $\begin{array}{c}{[2]} \\
\text { Policy }\end{array}$ & $\begin{array}{c}\text { [3] } \\
\text { Policy }\end{array}$ & $\begin{array}{c}{[4]} \\
\text { InVega }\end{array}$ & $\begin{array}{c}{[5]} \\
\text { InVega }\end{array}$ & $\begin{array}{c}\text { [6] } \\
\text { InVega }\end{array}$ & $\begin{array}{c}\text { [7] } \\
\text { InDelta }\end{array}$ & $\begin{array}{c}\text { [8] } \\
\text { InDelta }\end{array}$ & $\begin{array}{c}\text { [9] } \\
\text { InDelta }\end{array}$ \\
\hline $\begin{array}{l}\text { panel data } \\
\text { treatment: }\end{array}$ & pooled & $\begin{array}{c}\text { Newey- } \\
\text { West by } \\
\text { CEO }\end{array}$ & $\begin{array}{c}\text { Newey- } \\
\text { West by } \\
\text { CEO if no } \\
\text { large M\&A }\end{array}$ & pooled & $\begin{array}{c}\text { Newey- } \\
\text { West by } \\
\text { CEO }\end{array}$ & $\begin{array}{c}\text { Newey- } \\
\text { West by } \\
\text { CEO if no } \\
\text { large M\&A }\end{array}$ & pooled & $\begin{array}{c}\text { Newey- } \\
\text { West by } \\
\text { CEO }\end{array}$ & $\begin{array}{c}\text { Newey- } \\
\text { West by } \\
\text { CEO if no } \\
\text { large } M \& A\end{array}$ \\
\hline \multirow[t]{2}{*}{ NoninterestLess } & & & & 2.273 & 2.273 & 2.273 & $-3.802 * *$ & -3.802 & -3.802 \\
\hline & & & & [2.182] & [3.321] & [3.123] & [1.837] & [2.653] & [2.357] \\
\hline \multirow[t]{2}{*}{$\operatorname{lnVega}$} & $0.072^{* *}$ & 0.072 & $0.072 *$ & & & & $0.822 * * *$ & $0.822 * * *$ & $0.822 * * *$ \\
\hline & [0.032] & [0.052] & {$[0.038]$} & & & & {$[0.200]$} & {$[0.316]$} & {$[0.241]$} \\
\hline \multirow[t]{2}{*}{ InDelta } & $-0.068 * * *$ & $-0.068 * * *$ & $-0.068 * * *$ & 0.105 & 0.105 & 0.105 & & & \\
\hline & [0.017] & {$[0.026]$} & {$[0.023]$} & [0.269] & {$[0.411]$} & [0.382] & & & \\
\hline \multirow[t]{2}{*}{ Private $M B S$} & & & & -107.595 & -107.595 & -107.595 & 13.252 & 13.252 & 13.252 \\
\hline & & & & [103.117] & [144.961] & [120.754] & [8.799] & [11.061] & [9.333] \\
\hline \multirow[t]{2}{*}{ InVega } & $0.028 * *$ & 0.028 & $0.028^{*}$ & & & & 0.228 & 0.228 & 0.228 \\
\hline & [0.013] & [0.019] & {$[0.016]$} & & & & {$[0.251]$} & [0.328] & [0.275] \\
\hline \multirow[t]{2}{*}{ InDelta } & $0.013^{* *}$ & 0.013 & $0.013^{*}$ & 1.217 & 1.217 & 1.217 & & & \\
\hline & {$[0.006]$} & {$[0.010]$} & {$[0.008]$} & [1.414] & {$[2.026]$} & [1.594] & & & \\
\hline \multirow[t]{2}{*}{ Commercial } & & & & -1.807 & -1.807 & -1.807 & 0.796 & 0.796 & 0.796 \\
\hline & & & & [6.291] & [10.257] & [9.707] & [5.516] & [8.714] & [7.393] \\
\hline \multirow[t]{2}{*}{ InVega } & 0.011 & 0.011 & 0.011 & & & & $0.693 * * *$ & $0.693 * * *$ & $0.693 * * *$ \\
\hline & [0.012] & [0.019] & [0.015] & & & & [0.154] & [0.252] & [0.190] \\
\hline \multirow[t]{2}{*}{ InDelta } & $-0.020 * *$ & -0.020 & $-0.020 * *$ & -0.124 & -0.124 & -0.124 & & & \\
\hline & [0.008] & [0.012] & {$[0.010]$} & [0.185] & {$[0.285]$} & {$[0.257]$} & & & \\
\hline \multirow[t]{2}{*}{ Commercial RE } & & & & -0.488 & -0.488 & -0.488 & 0.219 & 0.219 & 0.219 \\
\hline & & & & [1.672] & [2.729] & [2.594] & [1.519] & [2.400] & [2.043] \\
\hline \multirow[t]{2}{*}{$\operatorname{lnVega}$} & $-0.048 * * *$ & $-0.048 *$ & $-0.048 * *$ & & & & $0.695^{* * *}$ & $0.695 * * *$ & $0.695 * * *$ \\
\hline & [0.018] & {$[0.026]$} & [0.023] & & & & {$[0.160]$} & [0.263] & [0.202] \\
\hline \multirow[t]{2}{*}{ InDelta } & $0.042^{* * *}$ & $0.042^{* * *}$ & $0.042 * * *$ & -0.063 & -0.063 & -0.063 & & & \\
\hline & {$[0.011]$} & {$[0.016]$} & [0.014] & [0.187] & [0.296] & {$[0.274]$} & & & \\
\hline \multirow[t]{2}{*}{ Mortgage } & & & & -0.948 & -0.948 & -0.948 & 0.431 & 0.431 & 0.431 \\
\hline & & & & [3.251] & [5.298] & [5.037] & [2.999] & [4.741] & [4.041] \\
\hline \multirow[t]{2}{*}{ lnVega } & $-0.036^{* *}$ & -0.036 & $-0.036 *$ & & & & $0.701 * * *$ & $0.701^{* *}$ & $0.701^{* * *}$ \\
\hline & {$[0.018]$} & [0.027] & {$[0.021]$} & & & & [0.185] & [0.305] & [0.241] \\
\hline \multirow[t]{2}{*}{ InDelta } & $0.019 *$ & 0.019 & 0.019 & -0.065 & -0.065 & -0.065 & & & \\
\hline & [0.011] & {$[0.017]$} & {$[0.014]$} & [0.182] & [0.287] & [0.265] & & & \\
\hline \multirow[t]{2}{*}{ Provisions } & & & & 20.984 & 20.984 & 20.984 & -29.299 & -29.299 & -29.299 \\
\hline & & & & [160.385] & [262.549] & [248.260] & [140.532] & [222.251] & [189.935] \\
\hline \multirow[t]{2}{*}{ lnVega } & $0.002^{* *}$ & $0.002 *$ & $0.002 * *$ & & & & $0.679 * * *$ & $0.679 * *$ & $0.679 * * *$ \\
\hline & [0.001] & [0.001] & [0.001] & & & & [0.185] & [0.281] & {$[0.220]$} \\
\hline \multirow[t]{2}{*}{ InDelta } & $-0.001 *$ & -0.001 & -0.001 & -0.095 & -0.095 & -0.095 & & & \\
\hline & {$[0.000]$} & {$[0.000]$} & {$[0.000]$} & [0.175] & {$[0.269]$} & [0.243] & & & \\
\hline
\end{tabular}


Table V Two-stage Least Squares Results after Controlling for Post-1999 Effects

This table displays selected two-stage least squares parameters from flexible specifications of equations (1), (2) and (3) that include post-1999 intercept and slope parameters. The parameters are estimated based on an unbalanced data panel of 881 annual observations for 134 different publicly traded U.S. banking companies from 1994 to 2006. Robust standard errors are reported in brackets. All variable definitions are included in Appendix Table A-I. The superscripts ***, **, and * indicate statistical significance at the $1 \%, 5 \%$, and $10 \%$ levels. The asterisks in the shaded SUM cells indicate whether the post-1999 influences of Policy, lnVega or lnDelta on the dependent variable were statistically significant.

\begin{tabular}{lccc}
\hline dependent variable: & {$[1]$} & {$[2]$} & {$[3]$} \\
panel data treatment: & $\begin{array}{c}\text { Policy } \\
\text { pooled }\end{array}$ & $\begin{array}{c}\text { InVega } \\
\text { pooled }\end{array}$ & $\begin{array}{c}\text { InDelta } \\
\text { pooled }\end{array}$ \\
\hline \multirow{3}{*}{ Systematic Risk } & & & \\
& & 0.162 & $2.096^{* *}$ \\
Post1999* & & {$[1.075]$} & {$[0.828]$} \\
Systematic Risk & & -1.091 & $-1.560^{*}$ \\
SUM & & {$[1.064]$} & {$[0.847]$} \\
lnVega & $0.387 * * *$ & & \\
& {$[0.070]$} & & $0.432 * *$ \\
Post1999*InVega & $-0.318^{* * *}$ & & $0.185]$ \\
& {$[0.043]$} & & {$[0.092]$} \\
SUM & & & $* * * *$ \\
InDelta & $-0.089 * *$ & -0.250 & \\
& {$[0.040]$} & {$[0.161]$} & \\
Post1999*InDelta & 0.037 & $0.316^{* *}$ & \\
& {$[0.048]$} & {$[0.153]$} & \\
SUM & & & \\
Post1999 & $0.890^{* * *}$ & 0.071 & -0.200 \\
& {$[0.165]$} & {$[0.524]$} & {$[0.557]$} \\
\hline
\end{tabular}

\begin{tabular}{|c|c|c|c|}
\hline $\begin{array}{l}\text { dependent variable: } \\
\text { panel data treatment: }\end{array}$ & $\begin{array}{c}\text { [1] } \\
\text { Policy } \\
\text { pooled } \\
\end{array}$ & $\begin{array}{c}{[2]} \\
\text { InVega } \\
\text { pooled } \\
\end{array}$ & $\begin{array}{c}{[3]} \\
\text { InDelta } \\
\text { pooled }\end{array}$ \\
\hline Private MBS & & $\begin{array}{c}6.341 \\
{[16.522]}\end{array}$ & $\begin{array}{l}13.569 \\
{[8.694]}\end{array}$ \\
\hline $\begin{array}{l}\text { Post1999* } \\
\text { Private MBS }\end{array}$ & & $\begin{array}{c}-27.882 * * * \\
{[6.971]}\end{array}$ & $\begin{array}{l}-1.046 \\
{[5.735]}\end{array}$ \\
\hline \multicolumn{4}{|l|}{ SUM } \\
\hline $\operatorname{lnVega}$ & $\begin{array}{c}0.031^{* * *} \\
{[0.008]}\end{array}$ & & $\begin{array}{c}0.202 \\
{[0.303]}\end{array}$ \\
\hline Post1999*InVega & $\begin{array}{l}-0.0002 \\
{[0.005]}\end{array}$ & & $\begin{array}{c}0.148^{* * *} \\
{[0.057]}\end{array}$ \\
\hline SUM & $* * *$ & & \\
\hline InDelta & $\begin{array}{c}0.006 \\
{[0.004]}\end{array}$ & $\begin{array}{c}-0.066 \\
{[0.317]}\end{array}$ & \\
\hline Post1999*InDelta & $\begin{array}{c}0.011 \\
{[0.007]}\end{array}$ & $\begin{array}{c}0.339 * * * \\
{[0.085]}\end{array}$ & \\
\hline SUM & $* * *$ & & \\
\hline Post1999 & $\begin{array}{c}-0.089 * * * \\
{[0.020]}\end{array}$ & $\begin{array}{c}-0.558 \\
{[0.505]}\end{array}$ & $\begin{array}{c}-0.716 * * \\
{[0.287]} \\
\end{array}$ \\
\hline
\end{tabular}

(continued on next page) 


\begin{tabular}{|c|c|c|c|c|c|c|c|}
\hline $\begin{array}{l}\text { dependent variable: } \\
\text { panel data treatment: }\end{array}$ & $\begin{array}{c}{[1]} \\
\text { Policy } \\
\text { pooled } \\
\end{array}$ & $\begin{array}{c}{[2]} \\
\text { InVega } \\
\text { pooled } \\
\end{array}$ & $\begin{array}{c}{[3]} \\
\text { InDelta } \\
\text { pooled } \\
\end{array}$ & $\begin{array}{l}\text { dependent variable: } \\
\text { panel data treatment: }\end{array}$ & $\begin{array}{c}{[1]} \\
\text { Policy } \\
\text { pooled } \\
\end{array}$ & $\begin{array}{c}{[2]} \\
\text { InVega } \\
\text { pooled } \\
\end{array}$ & $\begin{array}{c}3] \\
\text { InDelta } \\
\text { pooled } \\
\end{array}$ \\
\hline Idiosyncratic Risk & & $\begin{array}{l}-85.980 \\
{[179.030]}\end{array}$ & $\begin{array}{c}182.852 \\
{[113.877]}\end{array}$ & Commercial & & $\begin{array}{c}-17.613^{* *} \\
{[6.865]}\end{array}$ & $\begin{array}{c}-0.894 \\
{[5.856]}\end{array}$ \\
\hline $\begin{array}{l}\text { Post1999* } \\
\text { Idiosyncratic Risk }\end{array}$ & & $\begin{array}{c}-187.961 * * * \\
{[39.960]}\end{array}$ & $\begin{array}{l}-55.257 \\
{[38.591]}\end{array}$ & $\begin{array}{l}\text { Post1999* } \\
\text { Commercial }\end{array}$ & & $\begin{array}{c}21.654^{* * *} \\
{[4.694]}\end{array}$ & $\begin{array}{c}1.713 \\
{[3.921]}\end{array}$ \\
\hline SUM & & & & SUM & & & \\
\hline lnVega & $\begin{array}{c}0.002 \\
{[0.001]}\end{array}$ & & $\begin{array}{c}0.389 \\
{[0.269]}\end{array}$ & lnVega & $\begin{array}{c}0.018 \\
{[0.016]}\end{array}$ & & $\begin{array}{c}0.659 * * * \\
{[0.213]}\end{array}$ \\
\hline Post1999*InVega & $\begin{array}{c}0.004^{* * *} \\
{[0.001]}\end{array}$ & & $\begin{array}{c}0.099 \\
{[0.073]}\end{array}$ & Post1999*InVega & $\begin{array}{l}-0.022 * \\
{[0.012]}\end{array}$ & & $\begin{array}{l}0.137 * * \\
{[0.059]}\end{array}$ \\
\hline SUM & $* * *$ & & $* * *$ & SUM & & & $* * *$ \\
\hline InDelta & $\begin{array}{c}0.002 * * * \\
{[0.001]}\end{array}$ & $\begin{array}{c}-0.076 \\
{[0.142]}\end{array}$ & & InDelta & $\begin{array}{l}-0.017 \\
{[0.012]}\end{array}$ & $\begin{array}{l}-0.260 \\
{[0.187]}\end{array}$ & \\
\hline Post1999*InDelta & $\begin{array}{c}-0.005^{* * *} \\
{[0.001]}\end{array}$ & $\begin{array}{c}0.109 \\
{[0.078]}\end{array}$ & & Post1999*InDelta & $\begin{array}{c}0.002 \\
{[0.013]}\end{array}$ & $\begin{array}{c}0.199 * * * \\
{[0.077]}\end{array}$ & \\
\hline SUM & $* * *$ & & & SUM & & & \\
\hline Post1999 & $\begin{array}{l}0.007^{* *} \\
{[0.003]}\end{array}$ & $\begin{array}{c}2.905^{* * *} \\
{[0.793]}\end{array}$ & $\begin{array}{c}0.405 \\
{[0.717]}\end{array}$ & Post1999 & $\begin{array}{l}0.066^{*} \\
{[0.039]}\end{array}$ & $\begin{array}{c}-3.480^{* * *} \\
{[0.833]}\end{array}$ & $\begin{array}{l}-1.180^{*} \\
{[0.622]}\end{array}$ \\
\hline Total Risk & & $\begin{array}{l}-112.185 \\
{[176.129]}\end{array}$ & $\begin{array}{c}172.404 \\
{[114.070]}\end{array}$ & Commercial RE & & $\begin{array}{l}-1.330 \\
{[2.039]}\end{array}$ & $\begin{array}{l}-1.615 \\
{[2.121]}\end{array}$ \\
\hline $\begin{array}{l}\text { Post1999* } \\
\text { Total Risk }\end{array}$ & & $\begin{array}{c}-163.326^{* * *} \\
{[36.681]}\end{array}$ & $\begin{array}{l}-50.604 * \\
{[30.565]}\end{array}$ & $\begin{array}{l}\text { Post1999* } \\
\quad \text { Commercial RE }\end{array}$ & & $\begin{array}{l}-0.800 \\
{[1.983]}\end{array}$ & $\begin{array}{l}3.134^{*} \\
{[1.798]}\end{array}$ \\
\hline SUM & & & & SUM & & & \\
\hline lnVega & $\begin{array}{l}0.002^{*} \\
{[0.001]}\end{array}$ & & $\begin{array}{c}0.343 \\
{[0.279]}\end{array}$ & lnVega & $\begin{array}{c}-0.076 * * * \\
{[0.018]}\end{array}$ & & $\begin{array}{l}0.563 * * \\
{[0.263]}\end{array}$ \\
\hline Post1999*InVega & $\begin{array}{c}0.004^{* * *} \\
{[0.001]}\end{array}$ & & $\begin{array}{l}0.142^{* *} \\
{[0.058]}\end{array}$ & Post1999*InVega & $\begin{array}{c}-0.040 * * * \\
{[0.012]}\end{array}$ & & $\begin{array}{c}0.291 * * * \\
{[0.107]}\end{array}$ \\
\hline SUM & $* * *$ & & $* * *$ & SUM & $* * *$ & & $* * *$ \\
\hline InDelta & $\begin{array}{c}0.003 * * * \\
{[0.001]}\end{array}$ & $\begin{array}{l}-0.254^{*} \\
{[0.153]}\end{array}$ & & InDelta & $\begin{array}{c}0.052 * * * \\
{[0.011]}\end{array}$ & $\begin{array}{l}-0.046 \\
{[0.194]}\end{array}$ & \\
\hline Post1999*InDelta & $\begin{array}{c}-0.006 * * * \\
{[0.001]}\end{array}$ & $\begin{array}{c}0.266 * * * \\
{[0.079]}\end{array}$ & & Post1999*InDelta & $\begin{array}{c}0.009 \\
{[0.014]}\end{array}$ & $\begin{array}{c}0.168 \\
{[0.119]}\end{array}$ & \\
\hline SUM & $* * *$ & & & SUM & $* * *$ & & \\
\hline Post1999 & $\begin{array}{c}0.015^{* * *} \\
{[0.003]}\end{array}$ & $\begin{array}{c}2.252 * * * \\
{[0.719]} \\
\end{array}$ & $\begin{array}{c}0.188 \\
{[0.595]}\end{array}$ & Post1999 & $\begin{array}{c}0.257 * * * \\
{[0.043]} \\
\end{array}$ & $\begin{array}{c}0.113 \\
{[0.968]}\end{array}$ & $\begin{array}{c}-2.018^{* * *} \\
{[0.681]} \\
\end{array}$ \\
\hline
\end{tabular}

(continued on next page) 


\begin{tabular}{|c|c|c|c|c|c|c|c|}
\hline $\begin{array}{l}\text { dependent variable: } \\
\text { panel data treatment: }\end{array}$ & $\begin{array}{c}\text { [1] } \\
\text { Policy } \\
\text { pooled } \\
\end{array}$ & $\begin{array}{c}\text { [2] } \\
\text { InVega } \\
\text { pooled }\end{array}$ & $\begin{array}{c}\text { [3] } \\
\text { InDelta } \\
\text { pooled } \\
\end{array}$ & $\begin{array}{l}\text { dependent variable: } \\
\text { panel data treatment: }\end{array}$ & $\begin{array}{c}\text { [1] } \\
\text { Policy } \\
\text { pooled } \\
\end{array}$ & $\begin{array}{c}\text { [2] } \\
\text { InVega } \\
\text { pooled } \\
\end{array}$ & $\begin{array}{c}{[3]} \\
\text { InDelta } \\
\text { pooled } \\
\end{array}$ \\
\hline Noninterest & & $\begin{array}{c}1.495 \\
{[1.213]}\end{array}$ & $\begin{array}{c}-0.773 \\
{[0.971]}\end{array}$ & Mortgage & & $\begin{array}{c}-10.422^{* *} \\
{[4.646]}\end{array}$ & $\begin{array}{l}-4.455 \\
{[3.970]}\end{array}$ \\
\hline $\begin{array}{l}\text { Post1999* } \\
\text { Noninterest }\end{array}$ & & $\begin{array}{c}-0.340 \\
{[0.964]}\end{array}$ & $\begin{array}{c}-1.929 * * \\
{[0.872]}\end{array}$ & $\begin{array}{l}\text { Post1999* } \\
\text { Mortgage }\end{array}$ & & $\begin{array}{c}11.783^{* * *} \\
{[4.024]}\end{array}$ & $\begin{array}{l}7.017 * * \\
{[3.327]}\end{array}$ \\
\hline SUM & & & $* * *$ & SUM & & & \\
\hline $\ln V e g a$ & $\begin{array}{c}0.110 * * * \\
{[0.032]}\end{array}$ & & $\begin{array}{c}0.668 * * * \\
{[0.216]}\end{array}$ & $\operatorname{lnVega}$ & $\begin{array}{c}-0.080 * * * \\
{[0.023]}\end{array}$ & & $\begin{array}{l}0.610^{* *} \\
{[0.282]}\end{array}$ \\
\hline Post1999*InVega & $\begin{array}{c}0.066 * * * \\
{[0.021]}\end{array}$ & & $\begin{array}{c}0.304 * * * \\
{[0.086]}\end{array}$ & Post1999*InVega & $\begin{array}{c}0.047^{* * *} \\
{[0.016]}\end{array}$ & & $\begin{array}{c}0.186 * * * \\
{[0.057]}\end{array}$ \\
\hline SUM & $* * *$ & & $* * *$ & SUM & & & $* * *$ \\
\hline InDelta & $\begin{array}{c}-0.087 * * * \\
{[0.019]}\end{array}$ & $\begin{array}{c}-0.001 \\
{[0.244]}\end{array}$ & & InDelta & $\begin{array}{c}0.042^{* * *} \\
{[0.016]}\end{array}$ & $\begin{array}{c}-0.051 \\
{[0.183]}\end{array}$ & \\
\hline Post1999*InDelta & $\begin{array}{c}-0.058^{* *} \\
{[0.023]}\end{array}$ & $\begin{array}{l}0.232 * * \\
{[0.109]}\end{array}$ & & Post1999*InDelta & $\begin{array}{c}-0.036^{* *} \\
{[0.017]}\end{array}$ & $\begin{array}{c}0.284 * * * \\
{[0.084]}\end{array}$ & \\
\hline SUM & $* * *$ & & & SUM & & & \\
\hline Post1999 & $\begin{array}{c}-0.006 \\
{[0.067]}\end{array}$ & $\begin{array}{c}-0.414 \\
{[0.481]}\end{array}$ & $\begin{array}{c}-0.974 * * * \\
{[0.306]}\end{array}$ & Post1999 & $\begin{array}{c}0.056 \\
{[0.052]}\end{array}$ & $\begin{array}{c}-2.857 * * * \\
{[1.031]}\end{array}$ & $\begin{array}{c}-2.326^{* * *} \\
{[0.692]}\end{array}$ \\
\hline NoninterestLess & & $\begin{array}{c}0.956 \\
{[2.185]}\end{array}$ & $\begin{array}{c}-1.349 \\
{[1.748]}\end{array}$ & Provisions & & $\begin{array}{c}-376.939 * * \\
{[166.754]}\end{array}$ & $\begin{array}{c}91.595 \\
{[152.508]}\end{array}$ \\
\hline $\begin{array}{l}\text { Post1999* } \\
\text { NoninterestLess }\end{array}$ & & $\begin{array}{c}1.883 \\
{[1.492]}\end{array}$ & $\begin{array}{l}-2.974^{*} \\
{[1.719]}\end{array}$ & $\begin{array}{l}\text { Post1999* } \\
\text { Provisions }\end{array}$ & & $\begin{array}{c}456.119 * * * \\
{[153.564]}\end{array}$ & $\begin{array}{l}-180.611 \\
{[186.251]}\end{array}$ \\
\hline SUM & & & $* * *$ & SUM & & & \\
\hline $\operatorname{lnVega}$ & $\begin{array}{l}0.060^{* *} \\
{[0.030]}\end{array}$ & & $\begin{array}{c}0.614 * * * \\
{[0.224]}\end{array}$ & lnVega & $\begin{array}{c}0.002^{* * *} \\
{[0.001]}\end{array}$ & & $\begin{array}{l}0.574^{* *} \\
{[0.223]}\end{array}$ \\
\hline Post1999*InVega & $\begin{array}{c}0.048 * * * \\
{[0.018]}\end{array}$ & & $\begin{array}{c}0.335^{* * *} \\
{[0.121]}\end{array}$ & Post1999*InVega & $\begin{array}{c}0.001^{* * *} \\
{[0.000]}\end{array}$ & & $\begin{array}{l}0.272 * * \\
{[0.128]}\end{array}$ \\
\hline SUM & $* * *$ & & $* * *$ & SUM & $* * *$ & & $* * *$ \\
\hline InDelta & $\begin{array}{c}-0.036^{* *} \\
{[0.016]}\end{array}$ & $\begin{array}{c}0.047 \\
{[0.243]}\end{array}$ & & InDelta & $\begin{array}{c}0.000 \\
{[0.000]}\end{array}$ & $\begin{array}{c}-0.156 \\
{[0.177]}\end{array}$ & \\
\hline Post1999*InDelta & $\begin{array}{c}-0.061 * * * \\
{[0.021]}\end{array}$ & $\begin{array}{c}0.097 \\
{[0.117]}\end{array}$ & & Post1999*InDelta & $\begin{array}{c}-0.002 * * * \\
{[0.000]}\end{array}$ & $\begin{array}{l}-0.098 \\
{[0.129]}\end{array}$ & \\
\hline SUM & $* * *$ & & & SUM & $* * *$ & & \\
\hline Post1999 & $\begin{array}{l}0.122 * \\
{[0.063]}\end{array}$ & $\begin{array}{c}-0.127 \\
{[0.521]} \\
\end{array}$ & $\begin{array}{c}-1.149 * * * \\
{[0.310]} \\
\end{array}$ & Post1999 & $\begin{array}{c}0.005^{* * *} \\
{[0.001]} \\
\end{array}$ & $\begin{array}{r}0.359 \\
{[0.493]} \\
\end{array}$ & $\begin{array}{c}-0.998 * * * \\
{[0.317]} \\
\end{array}$ \\
\hline
\end{tabular}




\section{Figure 1 CEO Total Annual Compensation}

This figure reports the dollar value (in thousands of 2006 dollars) of total annual compensation (including salary, bonus, stock option grants, restricted stock grants, long-term incentive payouts, and other compensation) for CEOs in banks (881 observations) versus industrial firms (19,447 observations) from 1994 to 2006.

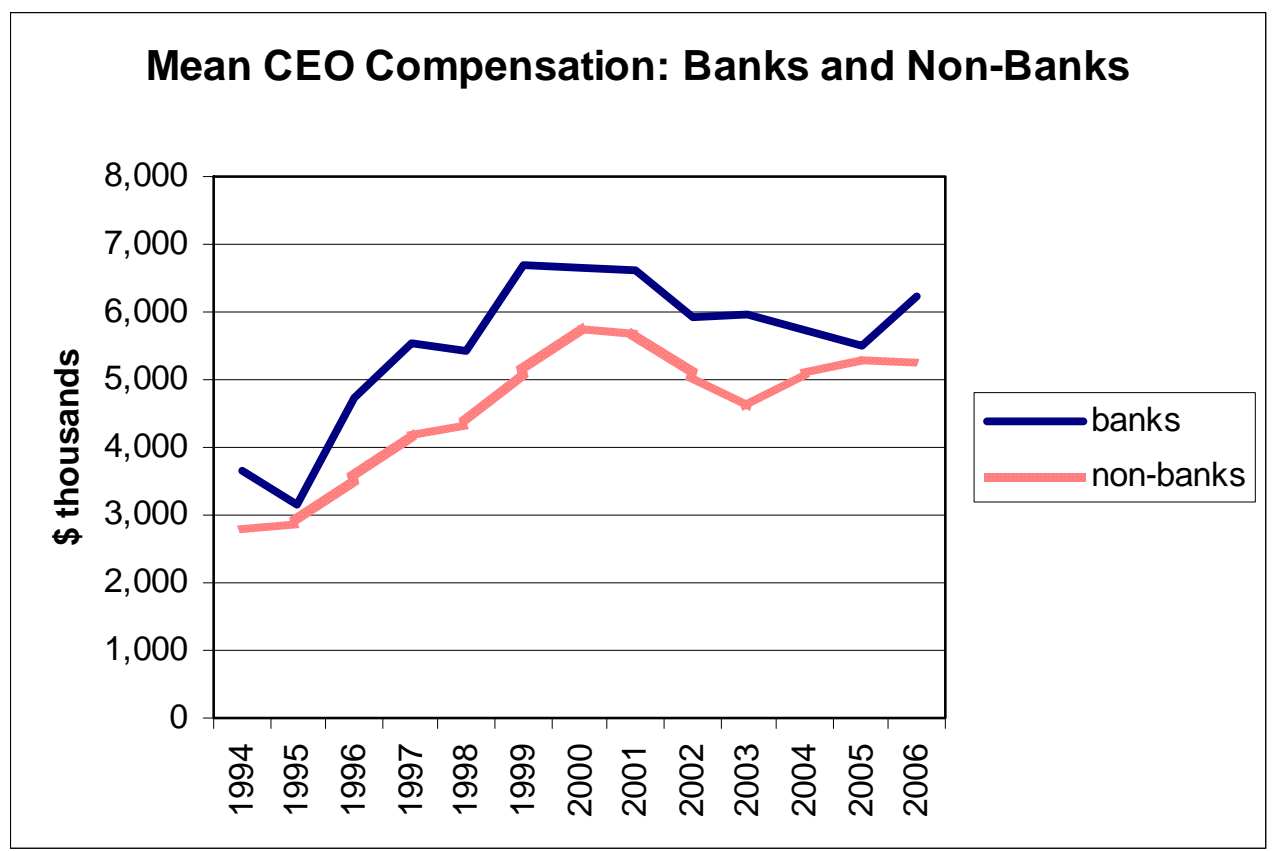




\section{Figure 2 CEO Vega}

This figure reports the dollar value (in thousands of 2006 dollars) of vega (the dollar change in the CEO's wealth for a 0.01 change in standard deviation of returns) for CEOs in banks (881 observations) versus industrial firms (19,447 observations) from 1994 to 2006.

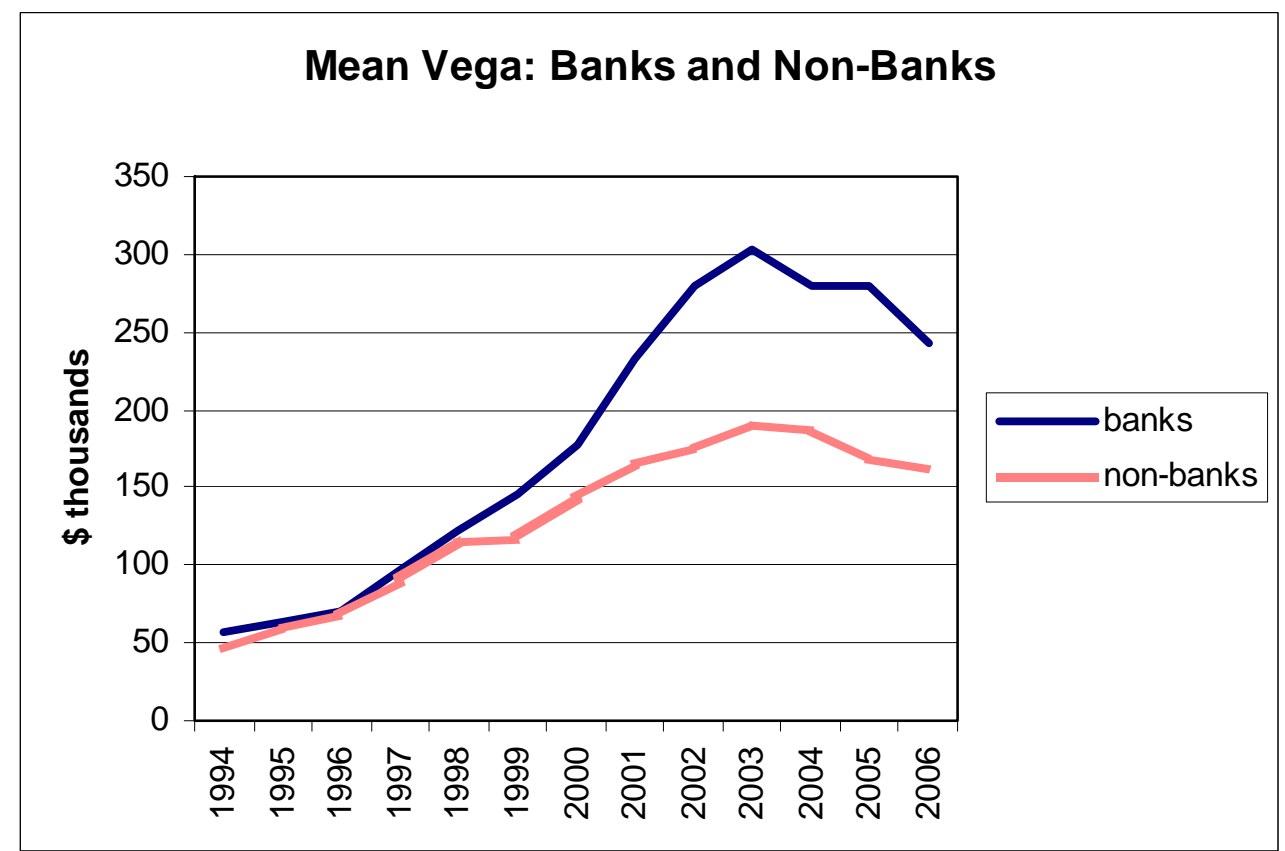




\section{Figure 3 CEO Delta}

This figure reports the dollar value (in thousands of 2006 dollars) of delta (the dollar change in the CEO's wealth for a $1 \%$ change in stock price) for CEOs in banks (881 observations) versus industrial firms (19,447 observations) from 1994 to 2006.

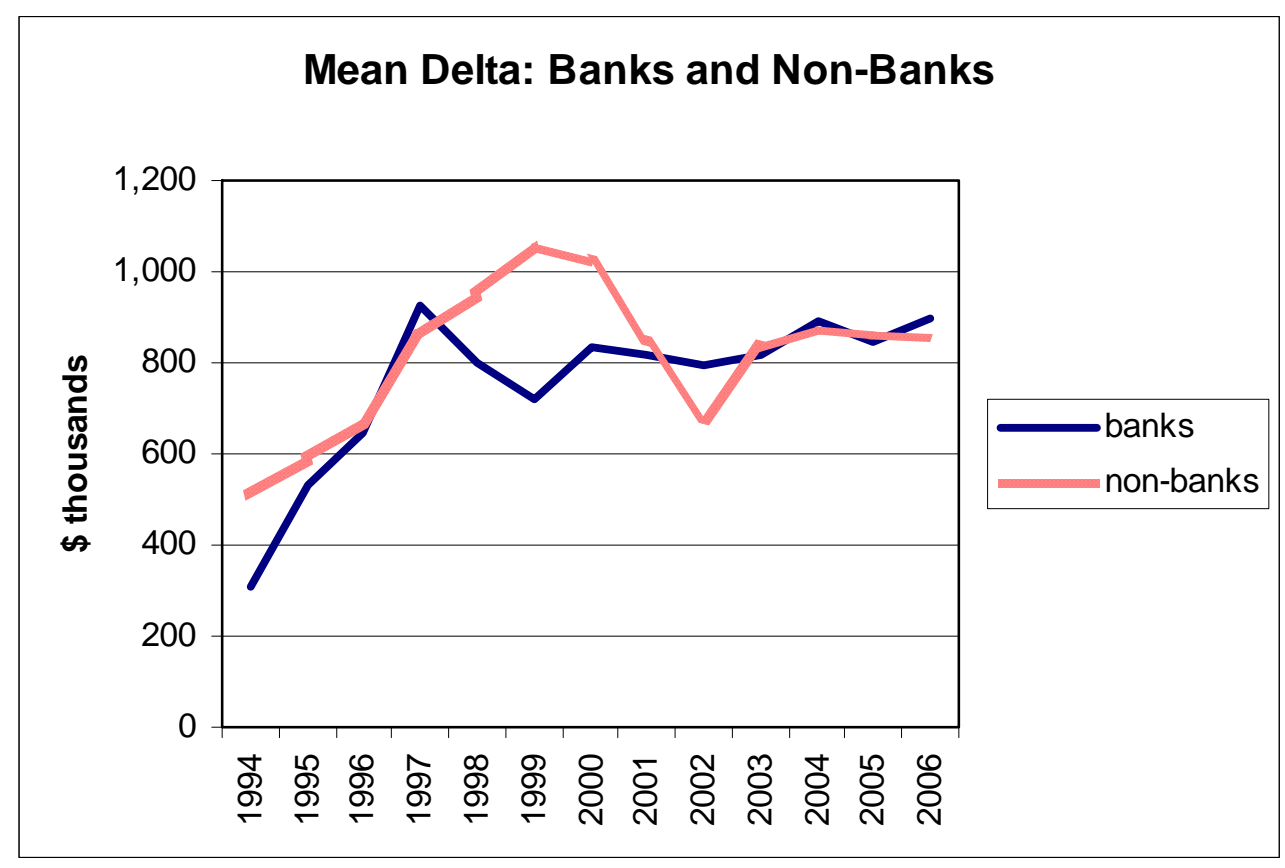




\section{Table A-I Variable definitions in alphabetical order*}

\begin{tabular}{|c|c|}
\hline Assets & The ending balance of total assets. \\
\hline Commercial & Commercial and industrial loans, scaled by total assets. \\
\hline Commercial RE & Commercial real estate loans, scaled by total assets. \\
\hline Delta & $\begin{array}{l}\text { The pay-performance sensitivity, which is the change in the dollar value of CEO wealth } \\
\text { for a } 1 \% \text { change in stock price, measured by partial derivatives of Black-Scholes value } \\
\text { of options and market value of stock holdings with respect to stock price. } \\
\text { Defined differently across the ten versions of our model, but is always constructed from } \\
\text { one of the following four different state-level data sources: the Federal Reserve Bank of }\end{array}$ \\
\hline EconCond & $\begin{array}{l}\text { Philadelphia's Coincident Index of economic conditions for each state; the per-capita } \\
\text { income for each state; and the payroll employment percentage for each state; and the } \\
\text { ratio of non-core deposits to total deposits for each bank. }\end{array}$ \\
\hline Equity Ratio & Total equity capital over total assets at the beginning of the year. \\
\hline Idiosyncratic Risk & The standard deviation of the three-factor market model residuals over a year. \\
\hline$M B$ & The ending balance of the market-to-book ratio of equity. \\
\hline Mortgage & Loans Secured by 1-4 family residential properties, scaled by total assets. \\
\hline Noninterest & Total noninterest income, scaled by net operating income. \\
\hline NoninterestLess & $\begin{array}{l}\text { Total noninterest income less fiduciary income and deposit service charges, scaled by } \\
\text { net operating income. }\end{array}$ \\
\hline Provisions & Provision for loan and lease losses, scaled by total assets. \\
\hline Private MBS & bThe fair value of private mortgage backed securities, scaled by total assets. \\
\hline Salary & The CEO's annual base salary. \\
\hline Systematic Risk & $\begin{array}{l}\text { The beta coefficient estimated from the three-factor market model over a year (The } \\
\text { three factors are daily returns on a CRSP value-weighted market portfolio, daily three- } \\
\text { month T-bill yields, and daily treasury yield spreads (10-yeare T-bond minus 2-year T- } \\
\text { note) obtained from the Federal Reserve Bank of St. Louis). }\end{array}$ \\
\hline Tenure & The number of years in the CEO's term. \\
\hline Total Risk & The standard deviation of daily stock returns over a year. \\
\hline Vega & $\begin{array}{l}\text { The pay-risk sensitivity, which is the change in the dollar value of CEO wealth for a } \\
0.01 \text { change in stock return volatility, measured by partial derivatives of Black-Scholes } \\
\text { value of options with respect to stock return volatility. }\end{array}$ \\
\hline
\end{tabular}

*All dollar values are in thousands of 2006 dollars. 
Table A-II: Full Regression Results for Systematic Risk

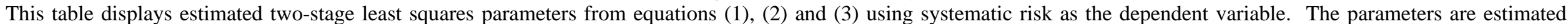

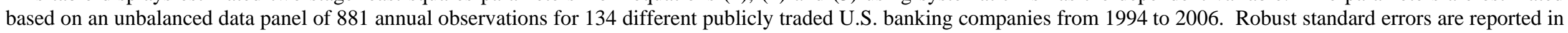
brackets. All variable definitions are included in Appendix Table A-I. The superscripts ***, **, and * indicate statistical significance at the $1 \%$, 5\%, and $10 \%$ levels.

\begin{tabular}{|c|c|c|c|c|c|c|c|c|c|}
\hline $\begin{array}{l}\text { dependent variable: } \\
\text { panel data treatment: }\end{array}$ & $\begin{array}{c}\text { [1] } \\
\text { Policy } \\
\text { pooled }\end{array}$ & $\begin{array}{c}\text { [2] } \\
\text { Policy } \\
\text { Newey- } \\
\text { West by } \\
\text { CEO }\end{array}$ & $\begin{array}{c}\text { [3] } \\
\text { Policy } \\
\text { Newey- } \\
\text { West by } \\
\text { CEO if no } \\
\text { large M\&A }\end{array}$ & $\begin{array}{c}{[4]} \\
\text { InVega } \\
\text { pooled }\end{array}$ & $\begin{array}{c}\text { [5] } \\
\text { lnVega } \\
\text { Newey- } \\
\text { West by } \\
\text { CEO }\end{array}$ & $\begin{array}{c}\text { [6] } \\
\text { InVega } \\
\text { Newey- } \\
\text { West by } \\
\text { CEO if no } \\
\text { large M\&A }\end{array}$ & $\begin{array}{c}\text { [7] } \\
\text { InDelta } \\
\text { pooled }\end{array}$ & $\begin{array}{c}\text { [8] } \\
\text { InDelta } \\
\text { Newey- } \\
\text { West by } \\
\text { CEO }\end{array}$ & $\begin{array}{c}\text { [9] } \\
\text { InDelta } \\
\text { Newey- } \\
\text { West by } \\
\text { CEO if no } \\
\text { large M\&A }\end{array}$ \\
\hline Systematic Risk & & & & $\begin{array}{l}-3.396 \\
{[2.148]}\end{array}$ & $\begin{array}{l}-3.396 \\
{[2.544]}\end{array}$ & $\begin{array}{c}-3.396 \\
{[2.426]}\end{array}$ & $\begin{array}{c}1.193 \\
{[0.742]}\end{array}$ & $\begin{array}{c}1.193 \\
{[1.030]}\end{array}$ & $\begin{array}{c}1.193 \\
{[0.893]}\end{array}$ \\
\hline lnVega & $\begin{array}{c}0.286 * * * \\
{[0.085]}\end{array}$ & $\begin{array}{c}0.286 * * \\
{[0.122]}\end{array}$ & $\begin{array}{c}0.286 * * * \\
{[0.105]}\end{array}$ & & & & $\begin{array}{c}0.481^{* * *} \\
{[0.143]}\end{array}$ & $\begin{array}{c}0.481 * * \\
{[0.218]}\end{array}$ & $\begin{array}{c}0.481 * * * \\
{[0.174]}\end{array}$ \\
\hline InDelta & $\begin{array}{c}-0.100 * * \\
{[0.045]}\end{array}$ & $\begin{array}{c}-0.1 \\
{[0.065]}\end{array}$ & $\begin{array}{l}-0.100 * \\
{[0.055]}\end{array}$ & $\begin{array}{c}-0.429 \\
{[0.311]}\end{array}$ & $\begin{array}{c}-0.429 \\
{[0.425]}\end{array}$ & $\begin{array}{c}-0.429 \\
{[0.391]}\end{array}$ & & & \\
\hline lnAssets & $\begin{array}{c}-0.081 \\
{[0.052]}\end{array}$ & $\begin{array}{c}-0.081 \\
{[0.073]}\end{array}$ & $\begin{array}{c}-0.081 \\
{[0.063]}\end{array}$ & $\begin{array}{c}0.822 * * * \\
{[0.206]}\end{array}$ & $\begin{array}{c}0.822 * * * \\
{[0.254]}\end{array}$ & $\begin{array}{c}0.822 * * * \\
{[0.242]}\end{array}$ & $\begin{array}{c}0.119 \\
{[0.096]}\end{array}$ & $\begin{array}{c}0.119 \\
{[0.151]}\end{array}$ & $\begin{array}{c}0.119 \\
{[0.112]}\end{array}$ \\
\hline $\ln M B$ & $\begin{array}{l}0.176^{*} \\
{[0.091]}\end{array}$ & $\begin{array}{c}0.176 \\
{[0.122]}\end{array}$ & $\begin{array}{c}0.176 \\
{[0.112]}\end{array}$ & $\begin{array}{l}1.710^{*} \\
{[0.934]}\end{array}$ & $\begin{array}{c}1.71 \\
{[1.178]}\end{array}$ & $\begin{array}{c}1.71 \\
{[1.089]}\end{array}$ & $\begin{array}{c}0.959 * * * \\
{[0.226]}\end{array}$ & $\begin{array}{c}0.959 * * * \\
{[0.321]}\end{array}$ & $\begin{array}{c}0.959 * * * \\
{[0.279]}\end{array}$ \\
\hline Equity Ratio & $\begin{array}{c}-1.748 * \\
{[0.990]}\end{array}$ & $\begin{array}{c}-1.748 \\
{[1.326]}\end{array}$ & $\begin{array}{c}-1.748 \\
{[1.160]}\end{array}$ & $\begin{array}{c}4.984 \\
{[3.823]}\end{array}$ & $\begin{array}{c}4.984 \\
{[5.670]}\end{array}$ & $\begin{array}{c}4.984 \\
{[5.300]}\end{array}$ & $\begin{array}{c}-2.853 \\
{[2.000]}\end{array}$ & $\begin{array}{c}-2.853 \\
{[2.739]}\end{array}$ & $\begin{array}{c}-2.853 \\
{[2.395]}\end{array}$ \\
\hline EconCond & $\begin{array}{c}0.008^{* * *} \\
{[0.002]}\end{array}$ & $\begin{array}{c}0.008 * * * \\
{[0.003]}\end{array}$ & $\begin{array}{c}0.008 * * * \\
{[0.003]}\end{array}$ & & & & & & \\
\hline InSalary & & & & $\begin{array}{c}1.770 * * * \\
{[0.554]}\end{array}$ & $\begin{array}{l}1.770 * * \\
{[0.776]}\end{array}$ & $\begin{array}{l}1.770 * * \\
{[0.696]}\end{array}$ & & & \\
\hline Tenure & & & & & & & $\begin{array}{c}0.050 * * * \\
{[0.005]}\end{array}$ & $\begin{array}{c}0.050 * * * \\
{[0.008]}\end{array}$ & $\begin{array}{c}0.050 * * * \\
{[0.007]}\end{array}$ \\
\hline constant & $\begin{array}{c}0.812 \\
{[0.644]} \\
\end{array}$ & $\begin{array}{c}0.812 \\
{[0.944]}\end{array}$ & $\begin{array}{c}0.812 \\
{[0.816]} \\
\end{array}$ & $\begin{array}{c}-19.880 * * * \\
{[4.510]}\end{array}$ & $\begin{array}{c}-19.880 * * * \\
{[5.953]}\end{array}$ & $\begin{array}{c}-19.880 * * * \\
{[5.454]}\end{array}$ & $\begin{array}{c}-0.734 \\
{[1.379]} \\
\end{array}$ & $\begin{array}{c}-0.734 \\
{[2.105]}\end{array}$ & $\begin{array}{c}-0.734 \\
{[1.654]}\end{array}$ \\
\hline $\begin{array}{l}\text { Year dummies } \\
\text { Kleibergen-Paap test of } \\
\text { under-identification }\end{array}$ & $\begin{array}{c}\text { yes } \\
17.965^{* * *}\end{array}$ & $\begin{array}{c}\text { yes } \\
9.045^{* * * *}\end{array}$ & $\begin{array}{c}\text { yes } \\
10.680 * * *\end{array}$ & $\begin{array}{c}\text { yes } \\
8.705^{* * *}\end{array}$ & $\begin{array}{c}\text { yes } \\
4.945^{* *}\end{array}$ & $\begin{array}{c}\text { yes } \\
5.942^{* *}\end{array}$ & $\begin{array}{c}\text { yes } \\
17.963^{* * *}\end{array}$ & $\begin{array}{c}\text { yes } \\
10.311^{* * *}\end{array}$ & $\begin{array}{c}\text { yes } \\
13.417 * * *\end{array}$ \\
\hline
\end{tabular}

